
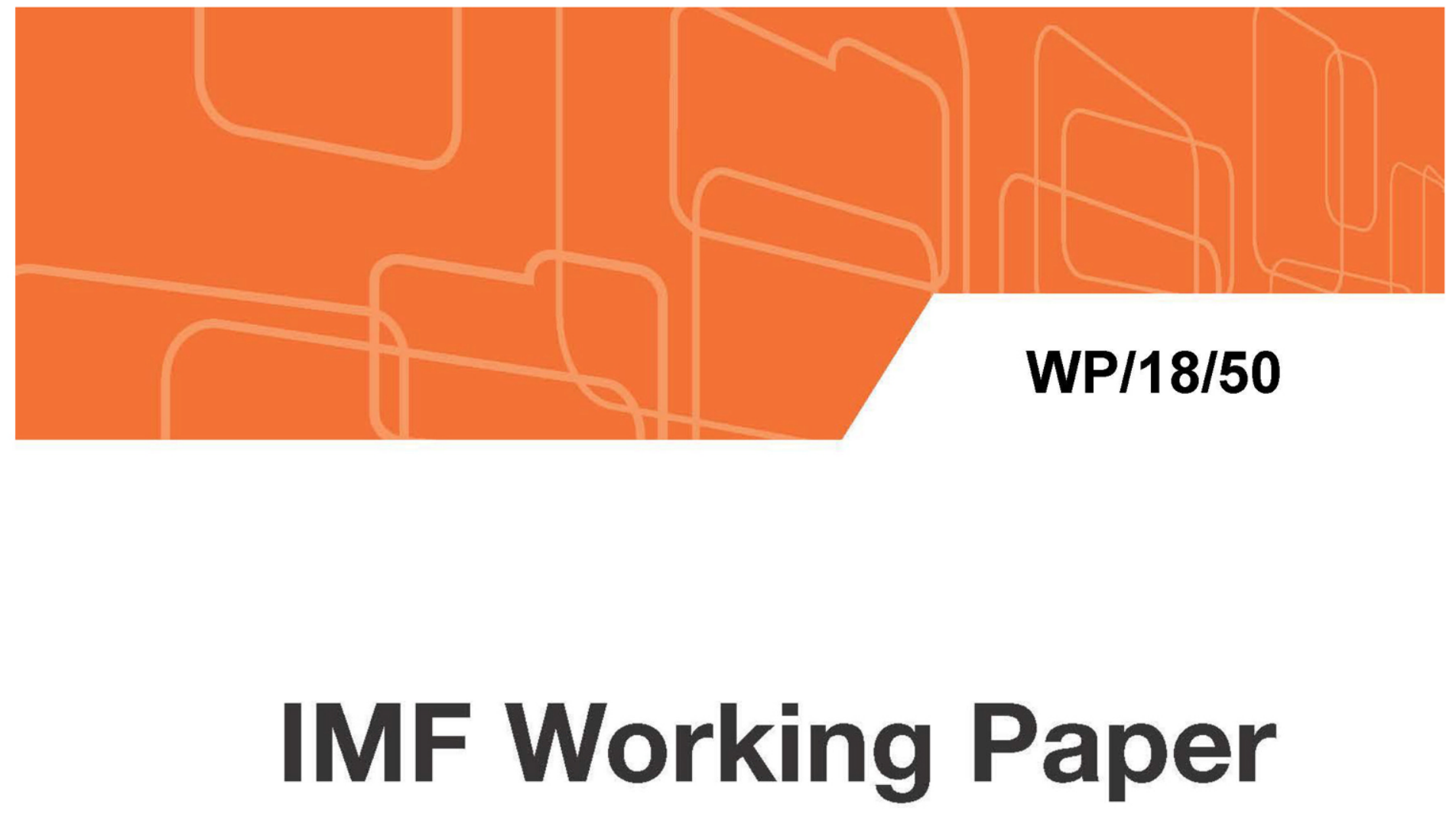

\title{
More Slack than Meets the Eye? Recent Wage Dynamics in Advanced Economies
}

by Gee Hee Hong, Zsóka Kóczán, Weicheng Lian, and Malhar Nabar

IMF Working Papers describe research in progress by the author(s) and are published to elicit comments and to encourage debate. The views expressed in IMF Working Papers are those of the author(s) and do not necessarily represent the views of the IMF, its Executive Board, or IMF management. 


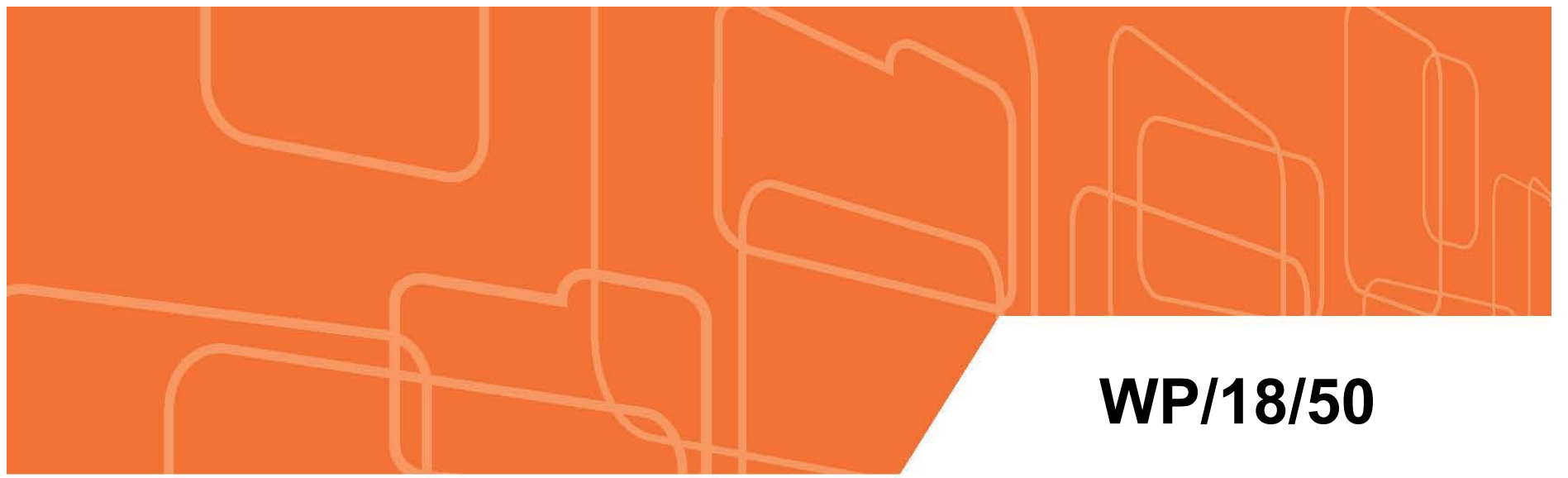

\section{IMF Working Paper}

\section{More Slack than Meets the Eye? Recent Wage Dynamics in Advanced Economies}

by Gee Hee Hong, Zsóka Kóczán, Weicheng Lian, and Malhar Nabar

IMF Working Papers describe research in progress by the author(s) and are published to elicit comments and to encourage debate. The views expressed in IMF Working Papers are those of the author(s) and do not necessarily represent the views of the IMF, its Executive Board, or IMF management. 


\title{
IMF Working Paper
}

Research Department

\section{More Slack than Meets the Eye? Recent Wage Dynamics in Advanced Economies ${ }^{1}$ \\ Prepared by Gee Hee Hong, Zsóka Kóczán, Weicheng Lian, and Malhar Nabar}

Authorized for distribution by Oya Celasun

March 2018

\begin{abstract}
IMF Working Papers describe research in progress by the author(s) and are published to elicit comments and to encourage debate. The views expressed in IMF Working Papers are those of the author(s) and do not necessarily represent the views of the IMF, its Executive Board, or IMF management.
\end{abstract}

\begin{abstract}
Nominal wage growth in most advanced economies remains markedly lower than it was before the Great Recession of 2008-09. This paper finds that the bulk of the wage slowdown is accounted for by labor market slack, inflation expectations, and trend productivity growth. In particular, there appears to be greater slack than meets the eye. Involuntary part-time employment appears to have weakened wage growth even in economies where headline unemployment rates are now at, or below, their averages in the years leading up to the recession.
\end{abstract}

JEL Classification Numbers: E31, E52, J21, J31

Keywords: wage growth, unemployment, involuntary part-time employment

Author's E-Mail Address: ghong@imf.org, zkoczan@imf.org, wlian@imf.org, mnabar@imf.org

\footnotetext{
${ }^{1}$ We thank Oya Celasun, Stephan Danninger, Bertrand Gruss, Gian Maria Milesi-Ferretti, Maury Obstfeld, Laura Papi, Petia Topalova, and seminar participants at the IMF's Research Department, LSE, OECD Paris, Paris School of Economics, Tokyo University, ANU Canberra, Chinese University of Hong Kong, RBA Sydney, Australia Department of Treasury (Canberra and Sydney), European Commission, ECB, Bank of Japan, Japan Ministry of Finance, Hong Kong Monetary Authority, IMF Regional Office for Asia and the Pacific (OAP Tokyo), and the IMF Singapore Regional Training Institute for helpful comments. Meron Haile, Ben Hilgenstock and Jungjin Lee provided excellent research and production assistance. The opinions expressed herein are those of the authors and do not necessarily reflect those of the International Monetary Fund.
} 


\section{Contents}

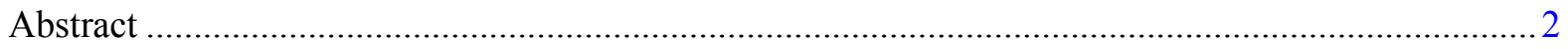

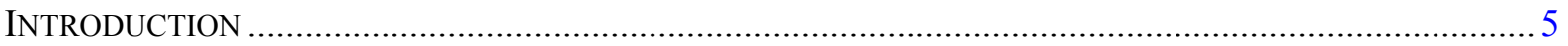

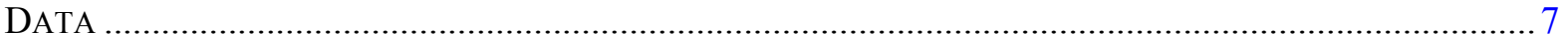

STYLIZED FACTS: SURFACE HEALING MASKS DEEPER CHANGES .................................................... 8

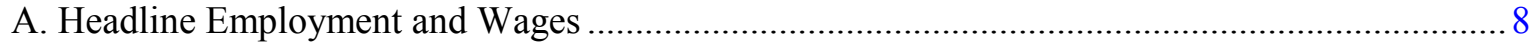

B. Involuntary Part-Time Employment, Temporary Contracts, Hours …….................................. 10

C. Separating Compositional Shifts from Common Patterns across Sectors ................................. 13

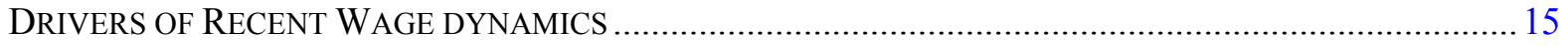

A. The Role of Traditional Measures of Slack ........................................................... 15

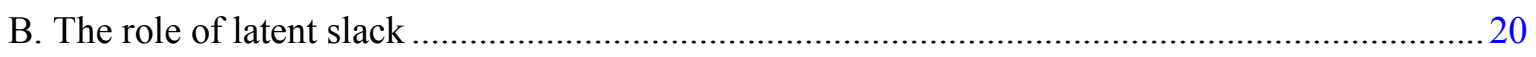

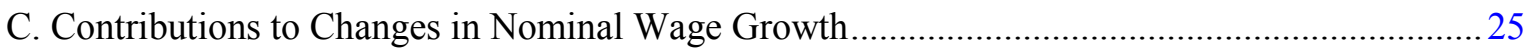

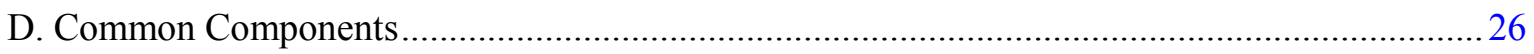

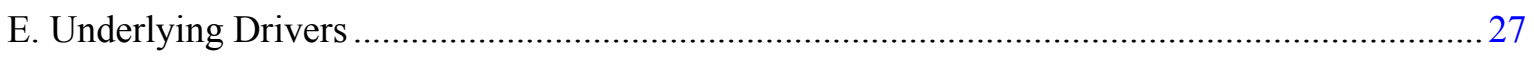

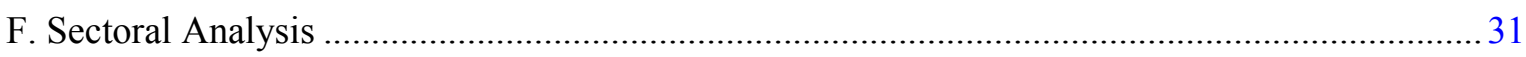

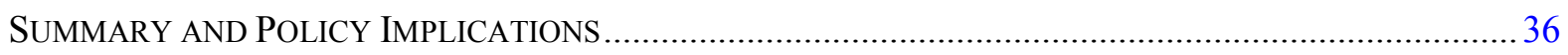

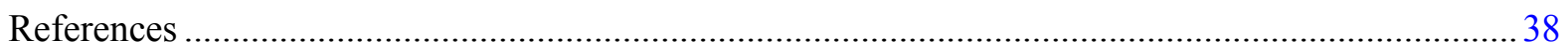

TABLES

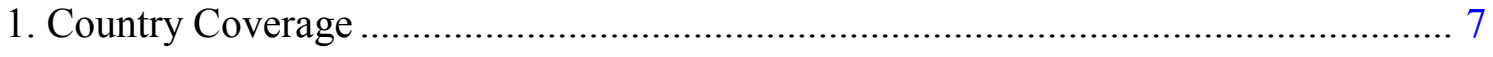

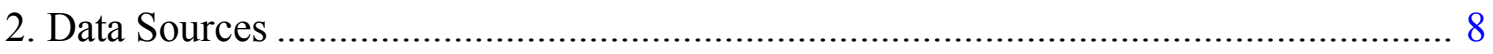

3. Estimates of Wage Phillips Curves ......................................................................... 18

4. Estimates of Wage Phillips Curves with Alternative Measures .................................20

5. Estimation of Wage Phillips Curve Augmented with Involuntary Part-Time

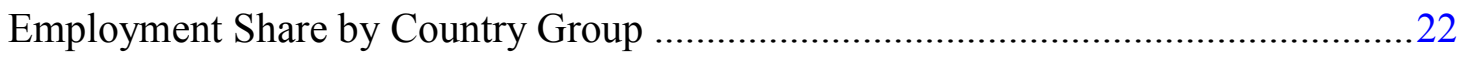

6. Estimation of Wage Phillips Curve Augmented with Involuntary Part-Time Employment Share: Full Sample and Countries with Unemployment Rates Lower

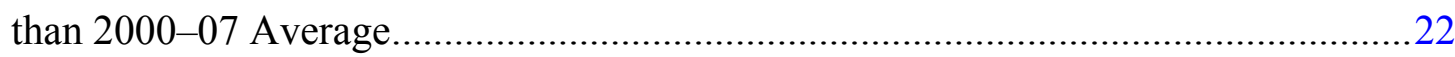

7. Estimation of Wage Phillips Curve Augmented with Involuntary Part-Time Employment Share: Countries with Unemployment Rates Moderately Higher and

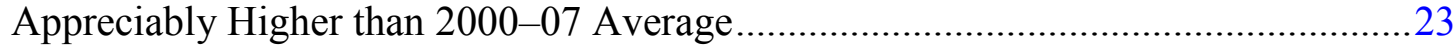

8. Estimation of Wage Phillips Curve Augmented with Structural Variables.................27

9. Estimation of Wage Phillips Curve Augmented with Structural Variables: Excluding Years 2008 and 2009 
10. Drivers of Involuntary Part-Time Employment Share, Aggregate Analysis .29

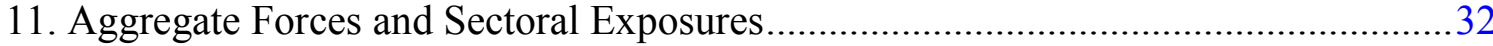

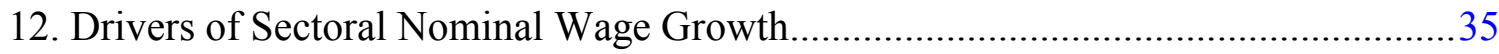

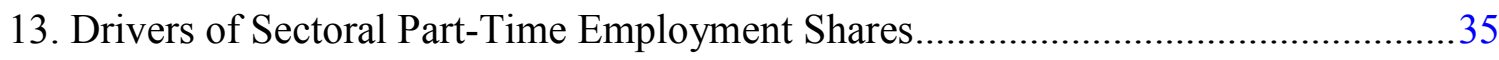

14. Drivers of Nominal Wage Growth, Employment Growth and Part-Time

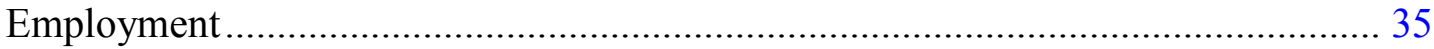

FIGURES

1. Distribution of Labor Market Indicators .................................................................

2. Distribution of Nominal Wage Growth and Correlation with Changes in the

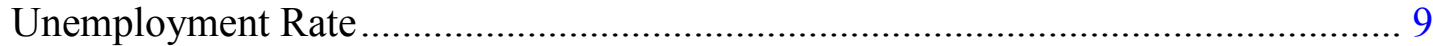

3. Job Attributes: Involuntary Part-Time Employment ........................................... 10

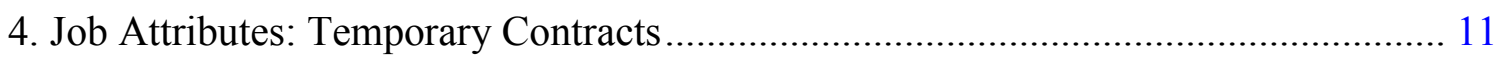

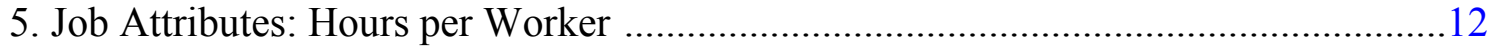

6. Average Nominal Wage Growth, 2009-16, Actual versus Imputed Using 2008 Sectoral Employment Shares

7. Changes in Labor Market Indicators, Actual versus Imputed Using 2008 Sectoral

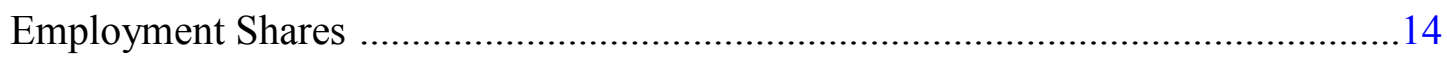

8. Job Attributes and Changes in Sectoral Employment Shares, 2008-16 ...................14

9. Effects on Growth of Compensation per Hour: Panel Estimation ............................19

10.Effects on Growth of Compensation per Hour: Country-by-Country Estimation, Cross-Country Dispersion .20

11. Effects of Involuntary Part-Time Employment on Growth of Compensation per Hour, 2000-16.

12. Effects of Involuntary Part-Time Employment on Compensation and Wages, $2000-16$ .24

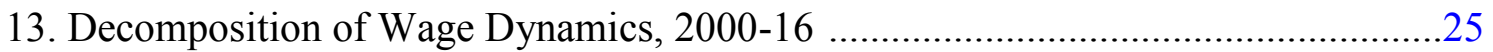

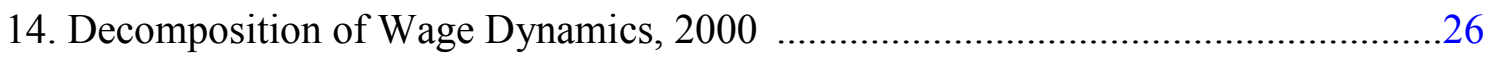

15. Year Fixed Effects and Common Drivers, 2000-16 ..........................................26

16. Changes in Growth Expectations and Labor Market Institutions ............................. 30

17. Long-Term Drivers of Labor Market Dynamics ..................................................30

18. Effects on Involuntary Part-Time Employment Share, Aggregate Analysis .............31

19. Decomposition of Sectoral Wage Dynamics, 2000-15 .........................................33

20. Effects on Part-Time Employment Share, Sectoral Analysis ................................34 


\section{INTRODUCTION}

Recent labor market developments in advanced economies point to a possible disconnect between unemployment and wages. Whereas in many economies headline unemployment is approaching ratios seen before the Great Recession, or has even dipped below those levels, nominal wages continue to grow at a distinctly slower pace. For some economies, this may reflect policy measures to slow wage growth and improve competitiveness in the aftermath of the global financial crisis and euro area sovereign debt crisis. But the pattern seems more widespread. Subdued nominal wage growth has also occurred in a context of a higher rate of involuntary part-time employment, an increased share of temporary employment contracts, and a reduction in hours per worker.

This paper studies the drivers of nominal wage dynamics in a broad sample of advanced economies, focusing on developments following the global financial crisis. From a macroeconomic perspective, shedding light on the forces shaping nominal wage developments could inform the debate on the extent of slack in the economy and the appropriate pace of exit from accommodative monetary policies. Core inflation rates in most advanced economies remain below targets and have not shown a sustained upswing even as growth has generally picked up since mid-2016. With wages being the largest component of most firms' production costs, the upswing in wages in response to falling unemployment is the main reason core inflation typically picks up as aggregate demand strengthens and excess capacity in the economy shrinks. ${ }^{2}$ A better understanding of the forces that weigh on wage growth is therefore important for assessing the appropriate course of monetary policy. Insights into the drivers of wage dynamics and the role of part-time employment and temporary contracts may also offer perspective on prospects for income inequality and possible policy actions to address the income security of workers with part-time jobs or temporary contracts. The latter could include tackling slack, supporting retraining and reskilling, addressing remaining labor market and structural rigidities, and ensuring fairness of treatment across employees under various types of contracts.

Accordingly, the paper addresses the following main questions:

- Drivers: How well do aggregate macroeconomic factors such as labor market slack, inflation expectations, and trend labor productivity growth account for nominal wage dynamics observed across advanced economies since the Great Recession? How has the evolving mix of full-time versus involuntary part-time employment and openended versus temporary work contracts affected labor market slack and hence wage dynamics?

\footnotetext{
${ }^{2}$ The part of the wage-inflation weakening attributable to lower productivity growth would not translate into weaker price inflation, given that the changes would have no net effect on cost pressures (proxied by unit labor costs).
} 
- Underlying changes: How have changes in firms' incentives and constraints in recent years (for example, related to changing expectations about medium-term growth prospects, technology, and global production processes) affected nominal wage setting and part-time employment? What impact have shifts in bargaining power (arising, for example, from changes in employment regulations, unionization, and degree of import competition) had on wages and part-time employment?

The paper finds that macroeconomic factors such as labor market slack (both headline unemployment and underutilization of labor in the form of involuntary part-time employment), inflation expectations, and trend productivity growth can account for the bulk of the variation in nominal wage growth at the country level in recent years. The analysis also suggests that common factors have been exerting increasing downward pressure on wage inflation in the aftermath of the global financial crisis and especially during 2014-16. For a number of euro area economies with large precrisis current account deficits, this may reflect policy measures to slow wage growth and improve competitiveness in the aftermath of the global financial crisis and euro area sovereign debt crisis. ${ }^{3}$ More broadly, the finding of sizable common factors behind wage weakness could indicate the growing effect on wage setting in any given economy of labor market conditions in other countries (in the context of stronger cross-border economic integration). It could also point to the role of broad-based and synchronized demand weakness across many countries and heightened concern about job losses, which may have hindered wage growth in the aftermath of the global financial crisis and the euro area sovereign debt crisis.

The relative roles of labor market slack and productivity growth vary across countries. In economies where unemployment rates are still appreciably above their averages before the Great Recession, conventional measures of labor market slack can explain about half of the slowdown in nominal wage growth since 2007, with involuntary part-time employment acting as a further significant drag on wages. Productivity growth is in turn relatively less important because these economies had generally lower productivity growth to begin with, and less of a slowdown.

In economies where unemployment rates are below their averages before the Great Recession, slow productivity growth can account for most - about two-thirds - of the slowdown in nominal wage growth since 2007 . However, even here, involuntary part-time employment appears to be weighing on wage growth, suggesting greater slack in the labor market than captured by headline unemployment rates.

Involuntary part-time employment has risen more in countries where output is estimated to fall short of its potential. Once the influence of slack is taken into account, involuntary parttime employment has increased more where medium-term growth expectations have fallen

\footnotetext{
${ }^{3}$ Also see Kang and Shambaugh (2014).
} 
more, automation has progressed faster, and the importance of services in the economy has increased.

The analysis suggests that while accommodative policies can help lift demand and lower headline unemployment rates, wage growth may continue to remain subdued until involuntary part-time employment diminishes or trend productivity growth picks up. Inflation rates will also likely remain low unless wage growth accelerates beyond productivity growth in a sustained manner. Assessing the true degree of slack beyond measured headline unemployment rates will be important when judging the appropriate pace of exit from accommodative monetary policies.

The paper is structured as follows: Section II discusses the data used, while Section III takes stock of changes in the labor markets of advanced economies over recent years. Section IV presents the empirical analysis, examining the forces shaping nominal wage dynamics and employment outcomes at the aggregate as well as sectoral levels. Section V concludes with a discussion of the main policy implications to be drawn from the analysis.

\section{DATA}

The aggregate analysis is based on both quarterly and annual data for 29 advanced economies during 2000: Q1-16: Q4. Sectoral regressions are based on annual data for 20 advanced economies during 2000-15.

The primary data sources for labor market variables are Eurostat, the Organization for Economic Co-operation and Development (OECD), and national authorities (Tables 1 and 2). Key sources for other variables used in this chapter are the Eora Multi-Region Input-Output database; Database on Institutional Characteristics of Trade Unions, Wage Setting, State Intervention and Social Pacts (ICTWSS), IMF World Economic Outlook database, and the OECD.

The next section examines the evolution of key labor market indicators in recent years.

\begin{tabular}{ll} 
Table 1. Country Coverage \\
\hline Aggregate Analysis & $\begin{array}{l}\text { Australia, Austria, Belgium, Canada, Czech Republic, Denmark, Estonia, Finland, France, Germany, } \\
\text { Greece, Iceland, Ireland, Israel, Italy, Japan, Korea, Lithuania, Netherlands, } \\
\text { New Zealand, Norway, Portugal, Slovak Republic, Slovenia, Spain, Sweden, Switzerland, United } \\
\text { Kingdom, United States }\end{array}$ \\
\hline Sectoral Analysis & $\begin{array}{l}\text { Australia, Austria, Belgium, Canada, Czech Republic, Denmark, Finland, France, Germany, Ireland, Italy, } \\
\text { Netherlands, Norway, Portugal, Spain, Slovak Republic, Slovenia, Sweden, United Kingdom, United } \\
\text { States }\end{array}$ \\
\hline
\end{tabular}




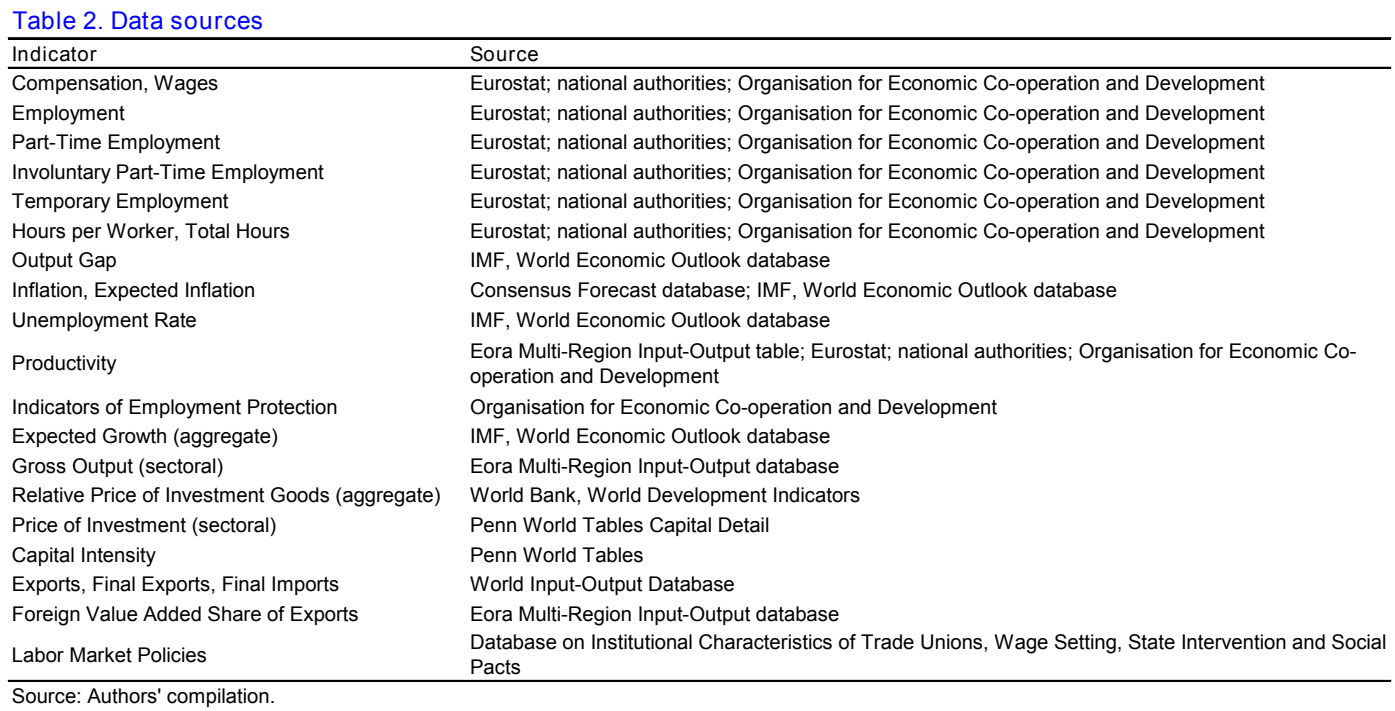

\section{STYLIZED FACTS: SURFACE HEALING MASKS DEEPER CHANGES}

\section{A. Headline Employment and Wages}

\section{Employment}

As shown in panel 1 of Figure 1, unemployment rates have been generally declining since 2013, but remain elevated in about three-quarters of advanced economies relative to their 2007 levels. These declines are mostly reflective of job creation, not artifacts of working-age members of the population dropping out of the labor force. In fact, as panel 2 shows, labor force participation has risen in more than half of advanced economies relative to 2007 levels, generally reflecting higher participation by workers older than 54 and women in these countries. ${ }^{4}$ Higher unemployment rates, combined with higher labor force participation rates, leave employment ratios (employed workers as share of the age $15+$ population) very close to or above their pre-Great Recession peak (2007) in about half of advanced economies. ${ }^{5}$

\section{Wages}

Panel 1 of Figure 2 shows that for virtually all advanced economies, nominal wage growth (measured as nominal compensation per hour, and comparable across countries) remains

\footnotetext{
${ }^{4}$ As highlighted in Chapter 1 of the October 2015 and October 2016 WEO, forecasts in the postcrisis period have generally overpredicted output growth and underpredicted employment growth in advanced economies, indicating that labor productivity has fallen short of predictions.

${ }^{5}$ There are some notable exceptions to this pattern. In the United States, a decline of 3 percentage points in the participation rate since 2007 has resulted in a lower employment ratio than before the crisis, despite the decline in the unemployment rate to below its precrisis level. In Germany and Japan, unemployment rates have fallen relative to their $2000-07$ averages.
} 
below pre-Great Recession ranges. ${ }^{6}$ This is particularly notable for economies where unemployment rates have declined relatively rapidly and are now close to or below preGreat Recession averages (Figure 2, panel 2). Even in economies where nominal wage growth in 2016 was higher than before the Great Recession, such as Germany and Japan, the gains have been from low bases: period of

Figure 1. Distribution of Labor Market Indicators (Percentage point difference relative to 2007)
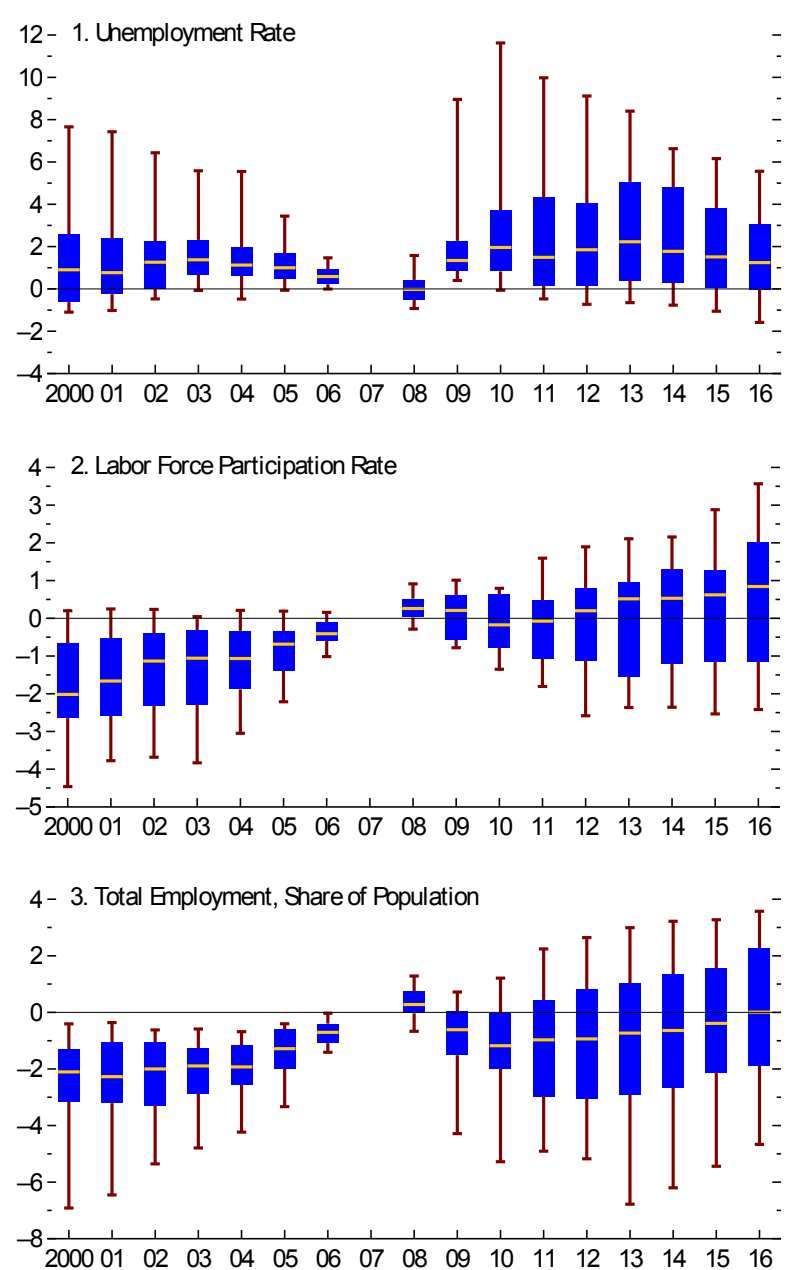

Sources: Organisation for Economic Co-operation and Development; and authors' calculations.

Note: The horizontal line inside each box represents the median, the upper and lower edges of the box show the top and bottom quartiles, and the red markers denote the top and bottom deciles. wage moderation in Germany intensified by the Hartz labor market reforms and in the midst of Japan's decade-long deflation and shrinking nominal wages. ${ }^{7}$ Figure 2. Distribution of Nominal Wage Growth and
Correlation with Changes in the Unemployment Rate
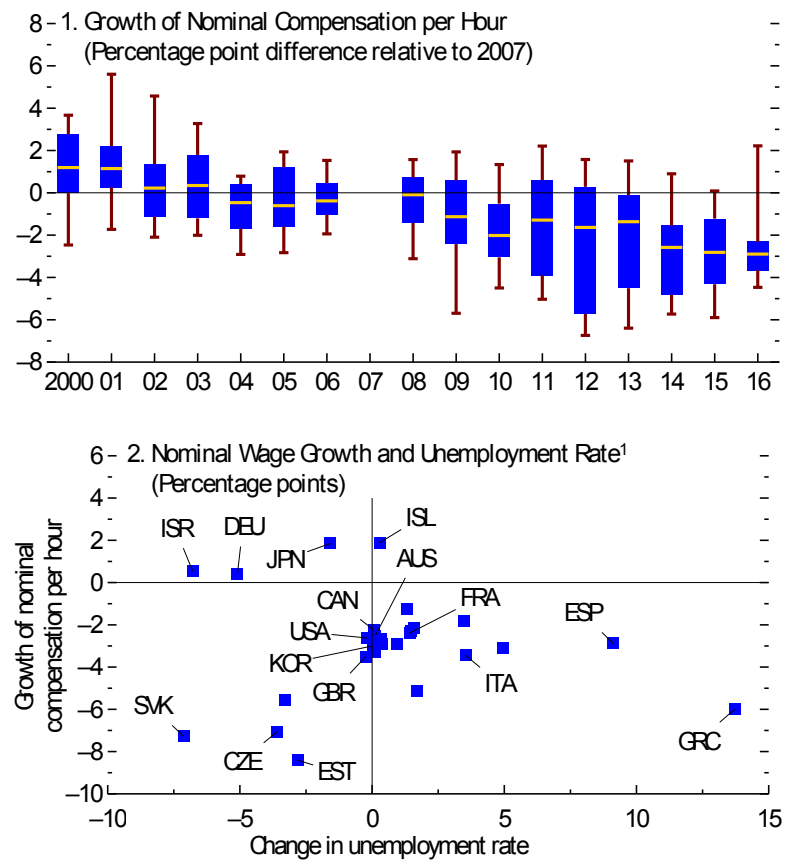

Sources: Eurostat; national authorities; Organisation for Economic Co-operation and Development; and authors' calculations.

Note: The sample in panel 1 excludes Baltic countries. The wage variable used is compensation per hour of workers excluding the self-employed. The horizontal line inside each box represents the median, the upper and lower edges of the box show the top and bottom quartiles, and the red markers denote the top and bottom deciles. Data labels in panel 2 use International Organization for Standardization (ISO) country codes. Ottliers and the ten largest advanced economies (by 2016 nominal GPP in US dollars) are labeled.

${ }^{1}$ Changes shown are 2016 values relative to the $2000-07$ average.

${ }^{6}$ Growth rates for real wages in about three-quarters of advanced economies are below what they were before the Great Recession, whether viewed as "consumption real wages" (that is, nominal wages deflated by headline consumer price inflation, which influences living standards and labor supply decisions) or as "product real wages" (that is, nominal wages deflated by the GDP deflator, which influences firms' profitability and hiring decisions).

${ }^{7}$ See Burda and Seele (2016) for a discussion of the effects of the Hartz reforms on the German labor market and Aoyagi and Ganelli (2015) on Japan's labor market outcomes during the 2000s. 


\section{B. Involuntary Part-Time Employment, Temporary Contracts, Hours}

Figure 3. Job Attributes: Involuntary Part-Time Employment
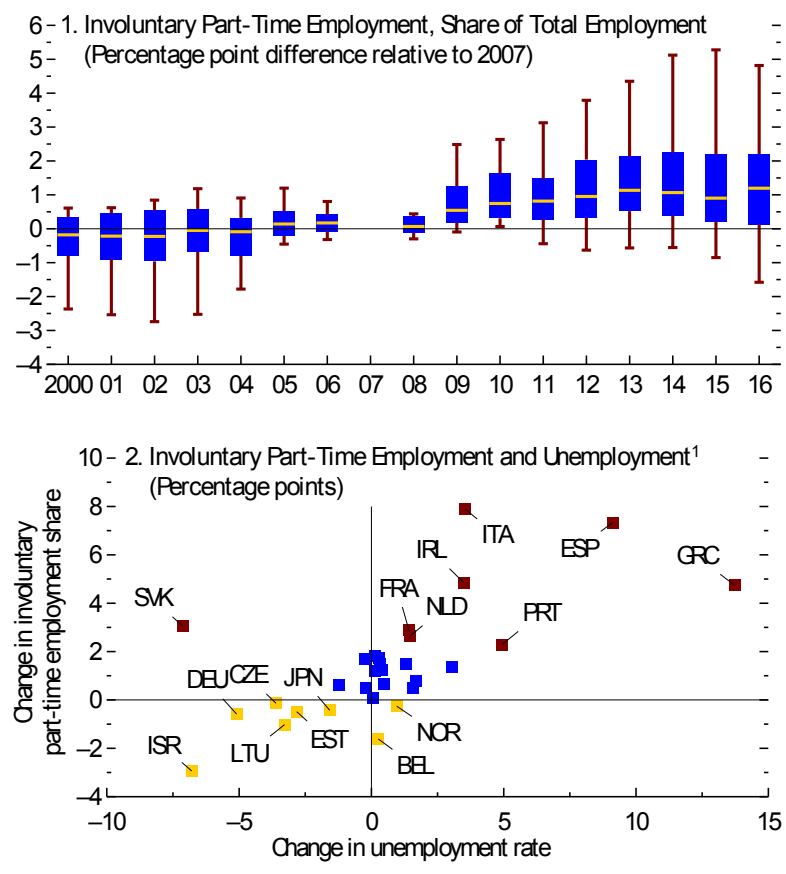

Sources: National authorities; Organisation for Economic Co-operation and Development; and authors' calculations.

Note: Involuntary part-time workers are those working less than 30 hours a week because they could not find a full-time position. The involuntary part-time employment share is calculated as the total number of involuntary part-time workers divided by total employment. In panel 1, the horizontal line inside each box represents the median, the upper and lower edges of the box show the top and bottom quartiles, and the red markers denote the top and bottom deciles. In panel 2, countries in gold are those with decreases in the involuntary part-time employment share; countries in red are those with pronounced increases. Data labels in the figure use International Organization for Standardization (ISO) country codes.

${ }^{1}$ Changes shown are 2016 values relative to the $2000-07$ average.
A more complete picture of the labor market emerges by considering additional indicators that suggest greater slack in the labor market than captured by headline unemployment rates, and possibly weaker job security than prior to the Great Recession.

\section{Involuntary Part-Time Employment}

Panel 1 of Figure 3 documents that involuntary part-time employment (workers employed fewer than 30 hours a week who report they would like longer hours) increased across virtually the entire sample in 2009 and remains above the 2007 level in more than three-quarters of countries. In the United States, the share increased from 0.8 percent in 2007 to 1.3 percent in 2016, while in the United Kingdom it rose from 2.4 percent to 3.9 percent, and in France from 5.3 percent to 7.8 percent. Germany is an exception, although its 2016 involuntary part-time employment share (3.1 percent) is above the 2.7 percent average for 2000-07.

As panel 2 of Figure 3 shows, the largest increases in involuntary part-time employment occurred in economies with unemployment rates above their 2000-07 averages. But even for economies with rates now close to their 2000-07 averages (points clustered around the vertical axis), the involuntary part-time share of employment is higher than it was before the crisis. 
Along with involuntary part-time employment, the incidence of temporary contractual arrangements has attracted attention in recent years (see Aoyagi and Ganelli 2015; and Brainard 2016). These contracts can help reduce unemployment spells, allow workers to avoid gaps in their employment history, and maintain their engagement in the labor force. However, they typically offer briefer employment than do open-ended contracts, less opportunity for workers to develop skills and expand responsibilities, and sometimes weaker benefits. By 2016, in just over half the economies, the temporary contract share was higher than in 2007 (Figure 4, panel 1). Temporary contracts are more common now than in 2000-07 for most advanced economies (Figure 4, panel 2). ${ }^{8}$

\section{Hours}

A third category of job attributes, which in part reflects worker preferences, is hours worked per worker. In more than half of the economies, hours per worker are at least 2 percent below pre-Great Recession levels (Figure 5 , panel 1). However, hours had been declining before that, and the pattern has continued.
Figure 4. Job Attributes: Temporary Contracts

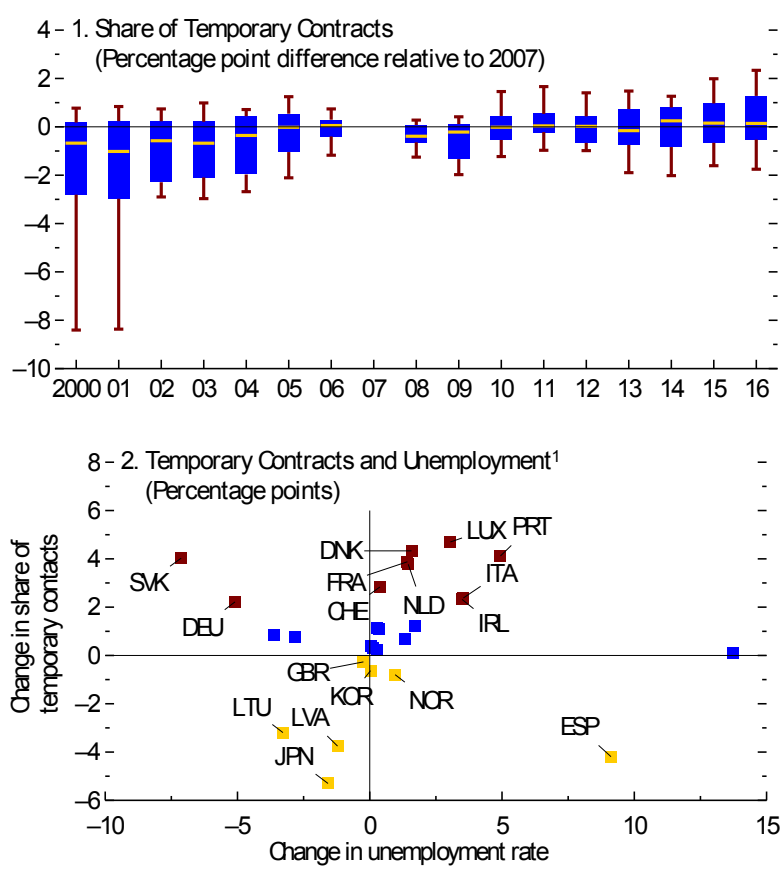

Sources: National authorities; Organisation for Economic Co-operation and Development; and authors' calculations.

Note: Temporary workers are people with work contracts of limited duration; thresholds are country specific. The share of temporary contracts is calculated as the number of temporary workers divided by total employment. In panel 1, the horizontal line inside each box represents the median, the upper and lower edges of the box show the top and bottom quartiles, and the red markers denote the top and bottom deciles. In panel 2, countries in gold are those with decreases in the share of temporary contracts; countries in red are those with pronounced increases. Data labels in the figure use International Organization for Standardization (ISO) country codes.

The

'Changes shown are 2016 values relative to the $2000-07$ average.

\footnotetext{
${ }^{8}$ In the case of Japan, the figure shows that the share of temporary contract workers has dropped by close to 6 percentage points compared with the 2000-07 average. But as noted in IMF (2016), the wider category of "nonregular" workers - (those who either (1) are not hired directly by the employer, (2) work part-time, or (3) do not have an open-ended contract - actually increased as a share of overall employment during this period. See also Aoyagi and Ganelli (2015). There is no comparable cross-country data on regular versus nonregular workers.
} 
Figure 5. Job Attributes: Hours per Worker
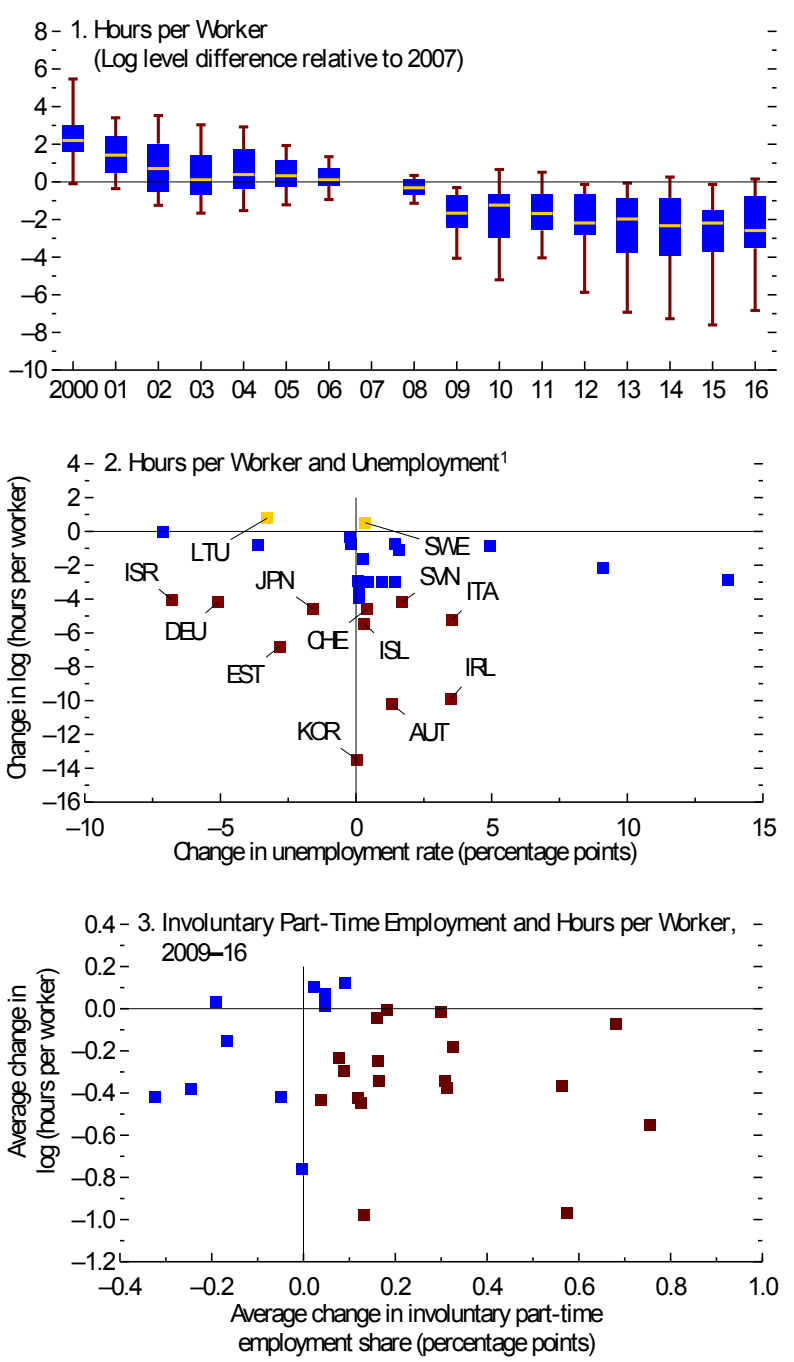

Sources: National authorities; Organisation for Economic Co-operation and Development; and authors' calculations.

Note: In panel 1, the horizontal line inside each box represents the median, the upper and lower edges of the box show the top and bottom quartiles, and the red markers denote the top and bottom deciles. In panel 2, countries in gold are those with increases in hours per worker; countries in red are those with pronounced decreases. In panel 3, countries in red display (on average) falling hours per worker and (on average) an increase in the involuntary part-time employment share for 2009-16. Data labels in the figure use International Organization for Standardization (ISO) country codes.

${ }^{1}$ Changes shown are 2016 values relative to the $2000-07$ average.
The decline in hours could reflect worker preferences for greater flexibility and willingness to work fewer hours (for example for elderly workers or students who previously may not have been in the labor force). But it could also reflect firms' preference for hiring workers for fewer hours or on an as-needed basis. These just-in-time matches are often governed by agreements between firms and workers. The firm need not guarantee minimum hours, and workers are not obligated to accept an offer made by the firm. These contracts are referred to as "zero-hours contracts" in the United Kingdom; similar agreements govern employment relationships elsewhere, including in Australia and Canada. ${ }^{9}$ Hours declined more in sectors with higher shares of low- and middle-skilled workers, suggesting that factors beyond worker preferences were at play. A concurrent rise in involuntary part-time employment also suggests that the decline in hours per worker was driven by reduced demand for hours of work by firms rather than reduced supply of hours by workers. The measure may understate the decline in hours per job if an individual now accumulates hours across multiple jobs more often than in the past. However, it is still difficult to separate workers' preferences that shape labor supply from the binding constraints of weak labor demand.

Hours per worker have fallen from their 2000-07 averages, regardless of whether unemployment rates are higher or lower than they were (Figure 5, panel 2). Declining hours also tend to be associated with higher shares of involuntary part-time employment (panel 3).

\footnotetext{
${ }^{9}$ In the United Kingdom for example, workers on zero-hours contracts as a share of employed workers rose from 0.6 percent in 2010 to 3 percent in 2016 (Haldane 2017).
} 


\section{Separating Compositional Shifts from Common Patterns across Sectors}

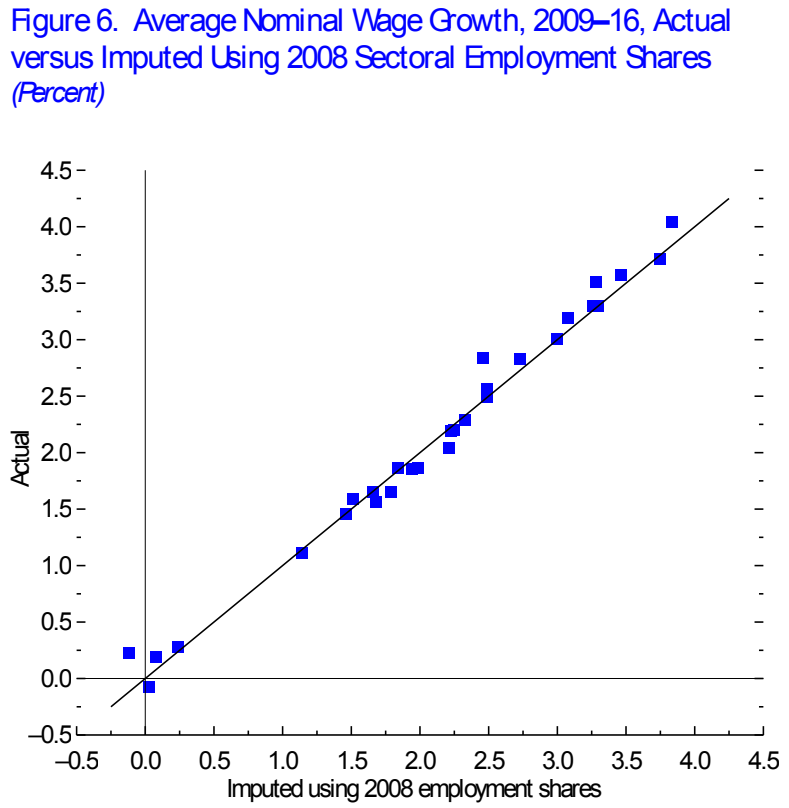

Sources: Eurostat; national authorities; and authors' calculations. Note: The wage variable used is annual wage per worker excluding the selfemployed.
The previous sections pointed to a widespread change in labor market outcomes (subdued wage growth, larger involuntary part-time employment, higher incidence of temporary contracts, declining hours per worker) compared with the period before the Great Recession. To what extent do these developments mostly reflect common patterns across sectors, or compositional shifts in employment toward sectors where the level or change in labor market outcomes is more pronounced? Data for 21 sectors across 31 advanced economies since 2000 allow for a deeper look at the underlying role of compositional effects.

Figures 6 and 7 compare the average

change in a job attribute during 2009-16 with the imputed change if employment shares across sectors had remained as they were in 2008. Points on the 45-degree line indicate that the actual change and the imputed change are identical, so it is therefore within-sector developments, rather than compositional change across sectors, that drive aggregate dynamics. Conversely, points off the 45-degree line indicate that compositional change contributed to the overall development. Points marked in red are those for which the indicator deteriorated during 2009-16 and compositional change in sectoral employment shares made a quantitatively important contribution to that decline (that is, a shift in employment toward sectors where the deterioration was deeper). The figures indicate that compositional changes seem to play greater roles for part-time employment shares, temporary contracts, and hours per worker than for growth in nominal wages. ${ }^{10}$

- In the case of part-time employment, 26 countries in the sample experienced an increased share of part-time workers. In 12 of the 26 countries, compositional change accounted for more than 25 percent of the increase (and more than half the increase in 4 countries).

\footnotetext{
${ }^{10}$ Labor mobility across sectors could cause wage growth to be broadly synchronized across sectors such that aggregate wage developments appear to reflect mostly within-sector developments.
} 
- $\quad$ Regarding the temporary contract share of employment, 19 of the 26 countries experienced an increase. Compositional change accounted for more than 25 percent of the increase in 7 of those countries (and more than half in 3 countries).

- Declines in hours per worker were seen in 25 countries, with compositional change accounting for more than 25 percent of this decrease in 10 countries (and more than half in 5 countries).

Figure 7. Changes in Labor Market Indicators, Actual versus Imputed Using 2008 Sectoral Employment Shares
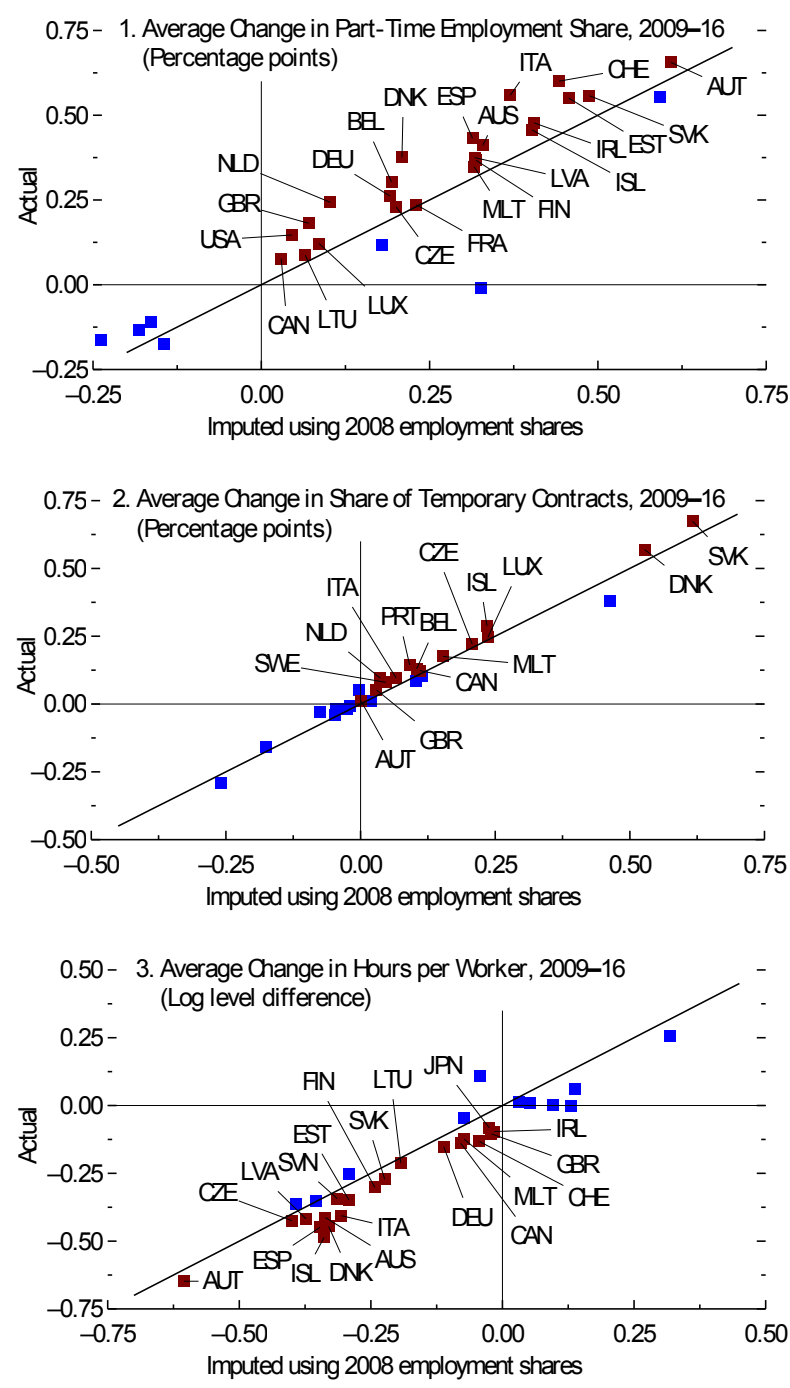

Sources: Eurostat; national authorities; and authors' calculations. Note: The part-time employment share is calculated as the number of part-time workers in a sector divided by total employment in the sector. Temporary workers are people with work contracts of limited duration; thresholds are country specific. The share of temporary contracts is calculated as the number of temporary workers in a sector divided by total employment in the sector. Countries in red represent cases in which compositional changes amplified within-sector increases (panels 1 and 2) or decreases (panel 3). Data labels in the figure use International Organization for Standardization (ISO) country codes.
Figure 8. Job Attributes and Changes in Sectoral Employment Shares, 2008-16
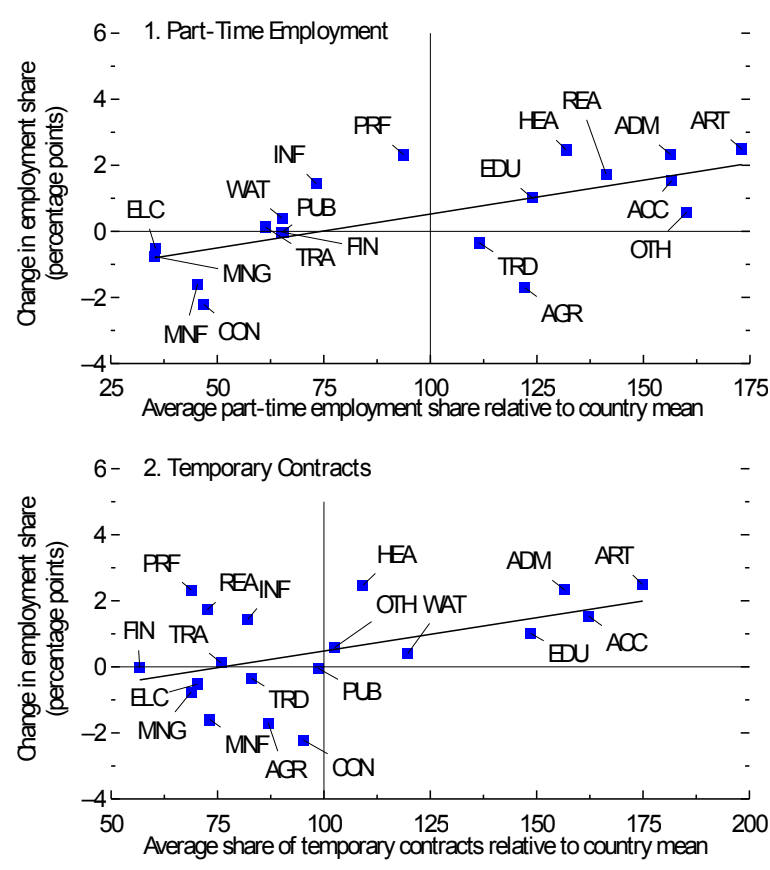

6- 3. Hours per Worker

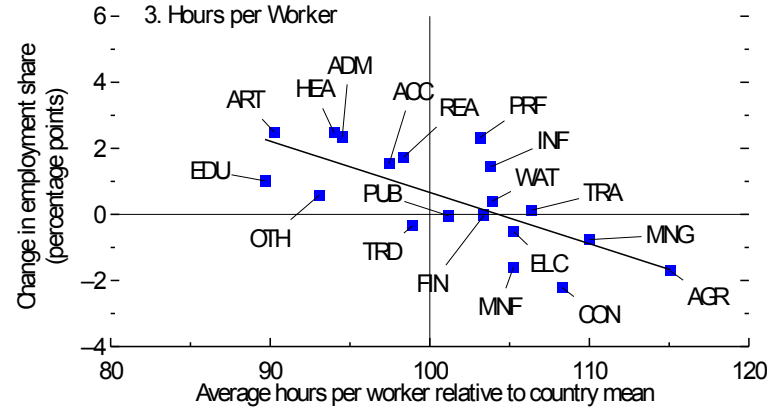

Sources: Eurostat; national authorities; Organisation for Economic Co-operation and Development; and authors' calculations.

Note: Markers to the right of 100 represent sectors with relatively high values (relative to country mean); markers to the left of 100 represent sectors with relatively low values. $A C C=$ accommodation and food service activities; $A D M=$ adminstrative and support service activities; $A G R=$ agriculture, forestry, and fishing; $A R T$ = arts, entertainment, and recreation; $C O N=$ construction; $B \mathrm{DU}=$ education; 且C= electricity, gas, steam, and air-conditioning supply; $\mathrm{FN}=$ financial and insurance activities; $\mathrm{HEA}=$ human health and social work activities; $\mathrm{INF}=$ information and communication; $\mathrm{MNF}=$ manufacturing; $\mathrm{MNG}=$ mining and quarrying; $\mathrm{OTH}=$ other services; $\mathrm{PPF}=$ professional, scientific, and technical activities; $P U B=$ public administration and defense; REA = real estate activities; $\mathrm{TRA}=$ transportation and storage; $\mathrm{TRD}=$ wholesale and retail trade; $\mathrm{WAT}=$ water supply, sewerage, waste management, and remediation activities. 
Panel 1 of Figure 8 shows that during 2009-16 declining employment shares in sectors with low part-time employment (mining and manufacturing), together with faster increases in employment in sectors with higher part-time employment shares (services), contributed to the rising share of part-time employment. A similar pattern emerged in temporary contract shares and hours per worker (Figure 8, panels 2 and 3).

In sum, sectors that tend to have traditional employment arrangements (smaller shares of temporary contracts and part-time employment, longer hours per worker) have seen outright declines or weaker growth in employment than sectors where arrangements are more flexible. All in all, shifts in employment shares across sectors can explain about 22 percent of the increase in part-time employment, 18 percent of the increase in temporary contracts, and 23 percent of the reduction in hours per worker.

\section{DRIVERS OF RECENT WAGE DYNAMICS}

As documented in Section III, nominal wage growth remains lower than before the Great Recession in most advanced economies. Furthermore, rising involuntary part-time employment, a higher incidence of temporary contracts, and a decline in hours per worker suggest broader changes in the labor market in many advanced economies since 2007, and notably even in those where unemployment rates are now below their precrisis averages.

This section studies the determinants of wage growth across advanced economies in recent years. The empirical approach first explores the role of cyclical factors, such as headline unemployment and inflation expectations and medium-term factors (trend productivity growth), before examining how the changing nature of employment affects wage dynamics. Finally, it explores the influence of slower-moving factors on wage dynamics and involuntary part-time employment.

\section{A. The Role of Traditional Measures of Slack}

The aggregate analysis uses a wage Phillips curve framework proposed by Gali (2011). The analysis focuses on nominal wage growth, examining the influence of past inflation and inflation expectations explicitly, alongside drivers that could be acting through real wage dynamics.

The original equation used by Gali (2011) is similar to equation (1): ${ }^{11} 12$

\footnotetext{
${ }^{11}$ The baseline wage measure is compensation per hour, excluding self-employment income. Because the data are insufficient to accurately determine the shares of value added captured by labor versus capital for the selfemployed, the baseline measure does not consider the wages of the self-employed. Results are broadly robust to using alternative wage measures.

${ }^{12}$ Gali's wage Phillips curve includes both the current and previous periods' unemployment rate given that the unemployment rate in the United States follows an autoregressive (2) process, in which the expected
} 


$$
\pi_{i, t}^{w}=\alpha_{i}+\theta \pi_{i, t-1}+\beta_{1} u_{i, t}+\beta_{2} \Delta u_{i, t}+\varepsilon_{i, t},
$$

in which, for country $i$ and time $t, \pi_{i, t}^{w}$ is the nominal wage growth, $\pi_{i, t-1}$ is lagged yearover-year inflation, $u_{i, t}$ is the unemployment rate, and $\Delta u_{i, t}$ is the change in the unemployment rate.

These cyclical drivers can be rationalized as follows. Nominal wage growth depends on expected inflation (if wage setting is forward looking) or on lagged inflation (if backward indexation occurs); in aggregate, it is likely to depend on a combination of the two. Given that the benchmark model assumes a constant natural rate of unemployment and constant hours per worker, the unemployment rate proxies for labor market slack. In other models, the output gap is used as an alternative measure of labor market slack. Greater slack in the labor market is expected to slow wage growth. Furthermore, at any given labor market slack and inflation expectations, wage growth can vary, depending on whether the economy is entering or exiting recession. The wage Phillips curves therefore also control for changes in unemployment (Manning 1993; Gali 2011).

In addition to the business cycle, a key force shaping average wage growth is trend labor productivity growth - increases in the output produced by each hour of labor input in combination with other factors of production. From firms' perspective, as trend labor productivity growth accelerates, the value of hiring additional workers increases relative to the cost of expanding the payroll. ${ }^{13}$ Greater demand for labor translates into rising vacancies relative to jobseekers, and therefore rising pressure on wages. As productivity growth weakens, all else equal, profitability declines, along with firms' ability to accommodate wage increases for their existing workers or their willingness to attract new workers with high wages. Thus, wage growth tends to weaken as productivity growth slows. Wage rigidities (Hall 2005; Taylor 2016) mean that changes in labor productivity may not translate one-for-

unemployment rate is a function of current and previous unemployment rates. The analysis in this paper uses a similar argument for controlling for the change in unemployment rate: it captures the expectation of the evolution of unemployment rates beyond the current rate. Intuitively, this captures the importance of whether a country enters a recession with rising unemployment rates or recovers from the recession with falling unemployment rates.

${ }^{13}$ The acceleration in labor productivity growth can occur through a combination of capital deepening (or an increase in the machinery and equipment each worker operates), improvements in human capital and the average skill composition of the workforce, and a faster pace of technology diffusion that complements the skills of a typical worker. The effects on particular types of workers may vary, depending on the complementarity of technological change with their skills and the tasks they perform, as discussed further below. 
one into wages immediately; ${ }^{14}$ wage growth is thus linked more to the trend of productivity growth (Dew-Becker and Gordon 2005; Yellen 2005). ${ }^{15} 16$

To explore how productivity growth as well as labor underutilization may affect aggregate wage growth, equation (1) is thus augmented with two sets of variables: trend productivity growth and labor market underutilization measures. The specification is as listed in Equation (2):

$$
\pi_{i, t}^{w}=\alpha_{i}+\theta \pi_{i, t-1}+\beta_{1} u_{i, t}+\beta_{2} \Delta u_{i, t}+\gamma \bar{g}_{i, t}^{Y / H}+\varphi \vec{Z}_{i, t}+\varepsilon_{i, t}
$$

in which $\bar{g}_{i, t}^{Y / H}$ is the trend of the growth rate of real output per hour, and $\vec{Z}_{i, t}$ are labor underutilization measures. These measures include the share of employed workers who take part-time jobs involuntarily, with part-time jobs defined as less than 30 hours a week, and the share of employed workers who have temporary work contracts.

The panel structure allows for the examination of wage dynamics across advanced economies, exploiting variation in the determinants of wage growth over time and across countries. Robustness tests are conducted by allowing the relationships between wage growth and labor market slack, changes in the unemployment rate, and inflation expectations to be country specific. Allowing coefficients to be country specific can help capture particular features of individual contexts - for instance, the hypothesis that nominal wage growth in the United States has been subdued in recent years in part because employers did not cut wages immediately after the financial crisis (Yellen 2014; Daly and Hobijn 2015), or the idea that wage growth may have been inhibited by a decline in the entry of new firms, a reduction in

\footnotetext{
${ }^{14} \mathrm{~A}$ one-for-one relationship between real wages and average labor productivity over the long term would require an elasticity of substitution between capital and labor of one. The elasticity of substitution between capital and labor is important in determining how the labor share in national income responds to changes in the relative costs of labor and capital.

${ }^{15}$ Of course, this link between wages and productivity may not strictly hold at the sectoral level (as illustrated by the Balassa-Samuelson effect).

${ }^{16}$ The inclusion of trend productivity growth in wage equations that examine the role of cyclical factors, such as slack and inflation expectations, is argued for by Ball and Moffitt (2001), Dew-Becker and Gordon (2005), Hall (2005), and Yellen (2005). The theoretical motivation for including productivity growth in wage Phillips curves is shown, for example, in Blanchard and Katz (1997), although the authors note that the empirical estimates for US Phillips curves estimated up to the time of writing do not strongly argue for its inclusion in the specification. The pass-through from labor productivity to real wages depends on the bargaining power of workers and the elasticity of substitution between capital and labor (Chapter 3 of the April 2017 WEO).
} 
labor market "churn," and fewer job-to-job transitions - and thus fewer discrete increases in wages that often occur with these transitions. ${ }^{17}$

Tables 3 and 4 show estimates of wage Phillips curves using ordinary least squares and instrumental variables estimations, for the full sample as well as a sample excluding the Baltic countries, and for alternative measures of the dependent and explanatory variables. Ordinary least squares estimates are shown as the baseline and include country and year fixed effects to account for time-invariant country-specific unobservables and common unobservable trends across countries.

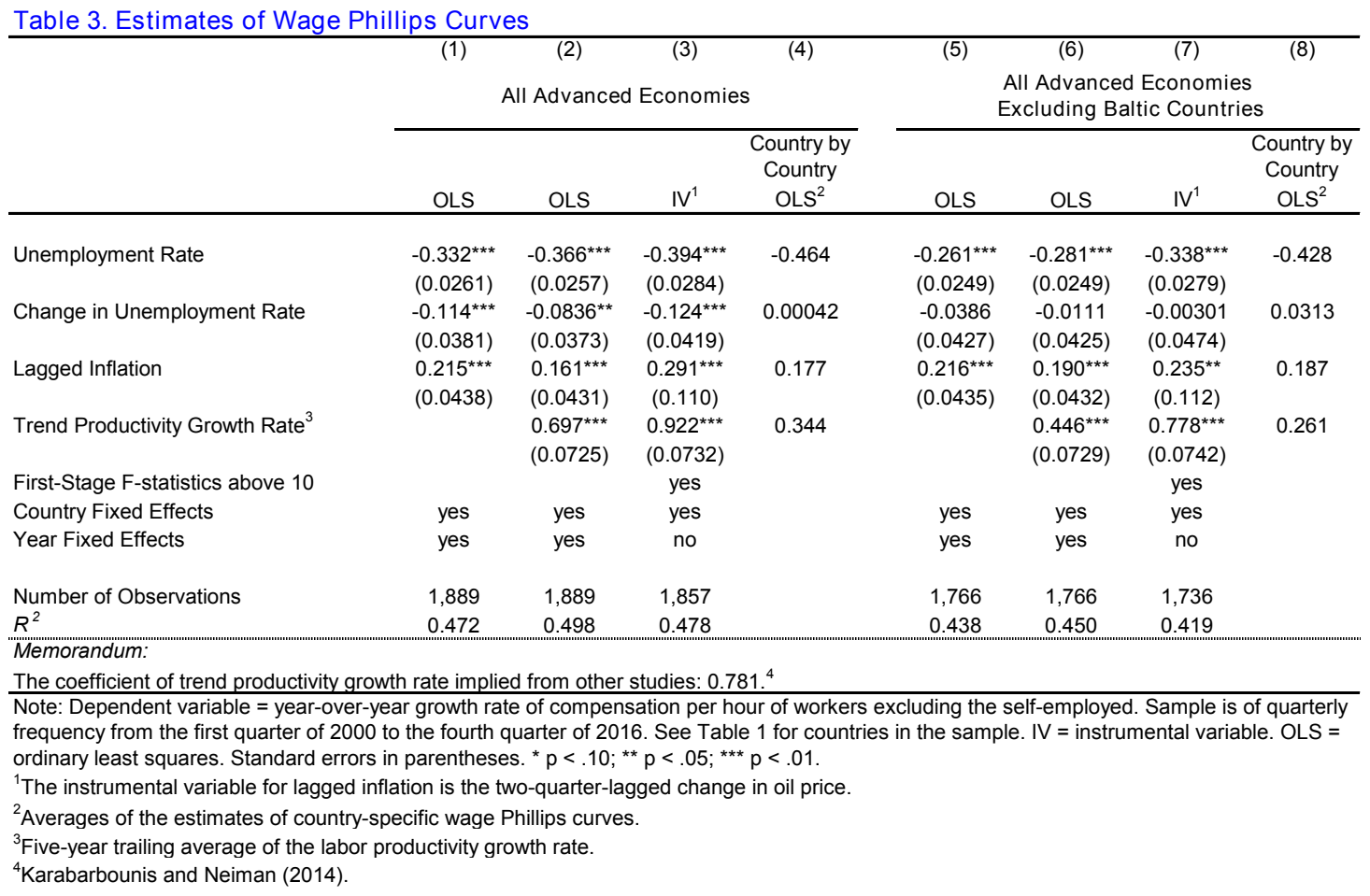

\section{Slack and inflation}

The analysis indicates that slack and past inflation are statistically significantly associated with nominal wage growth, with expected signs (Table 3, column 1). A 1 percentage point increase in the unemployment rate is associated with a 0.3 to 0.4 percentage point decline in nominal wage growth, while a 1 percentage point increase in lagged inflation is associated with a 0.2 percentage point increase in nominal wage growth.

\footnotetext{
${ }^{17}$ Danninger (2016), for example, finds that job-to-job transitions in the United States have slowed for all skill and age groups in recent years. These developments are not necessarily a legacy of the Great Recession. Davis and Haltiwanger (2014) show that worker reallocation rates declined by 25 percent after 2000, suggesting that the labor market had begun to turn less fluid before the Great Recession.
} 


\section{Trend labor productivity growth}

Firms' profitability and ability to accommodate wage increases are linked to changes in trend labor productivity growth, as discussed in the section on wage determination. The empirical evidence suggests that nominal wage growth indeed appears to move broadly in line with trend productivity growth (Table 3, column 2). A 1 percentage point increase in trend productivity growth is associated with a 0.7 percentage point increase in nominal wage growth. ${ }^{18}$

\section{Instrumental variables}

One concern with the baseline specification is that reverse causality from wage growth to price inflation may occur if firms pass faster growth in labor costs on in the prices they charge. This is addressed by instrumenting lagged inflation with past changes in oil prices. As seen in Table 3, column 4, the main result holds with the instrumental variables estimation.

\section{Alternative country sample}

The main results are robust to excluding smaller advanced economies (Table 3, columns 5-7). Figure 9 shows coefficient estimates for the preferred specification, based on the sample excluding the smaller economies and using instrumental variables to account for the endogeneity of inflation in the wage equation (Table 3, column 7). Furthermore, a country-by-country exploration of the influences of slack, past inflation, and trend productivity growth illustrates that the underlying dispersion of country-specific
Figure 9. Effects on Growth of Compensation per Hour: Panel Estimation

(Percentage points)

$1.0-$

$0.5-$

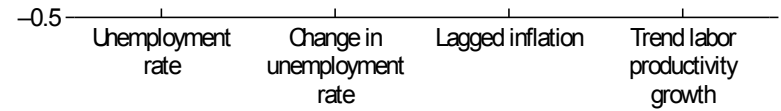

Source: Authors' calculations

Note: The wage variable used is compensation per hour of workers excluding the self-employed. Markers show estimated coefficients, and lines display 90 percent confidence intervals. Sample excludes the Baltic countries. Ol price is used as an confidence intervals. Sample excludes the Baltic countries. Ql price is used
instrument for lagged inflation. Figure is based on column (7) of Table 3.

\footnotetext{
${ }^{18}$ The impact of trend productivity growth on wage growth is consistent with other studies. These results suggest that a 1 percentage point increase in trend productivity growth rate is associated with 0.4 to 0.9 percentage point higher wage growth, a range that includes the impact of about 0.8 percentage point implied in Karabarbounis and Neiman (2014). A coefficient smaller than 1 implies a less than one-for-one association between increments to productivity growth and wage growth, and indicates that some of the gains from higher productivity growth translate into higher capital income (including rent, interest, dividends and retained corporate earnings). See Chapter 3 of the April 2017 WEO for a more extensive discussion.
} 
estimates (Figure 10; Table 3, columns 4 and 8 ) is broadly consistent with the coefficients obtained from the cross-country panel. ${ }^{19}$

Aggregate output gap as an alternative measure of slack

The findings also hold when using the aggregate output gap as a measure of slack (which allows for changes over time in the natural rate of unemployment and cyclical variations in hours per worker), as well as alternative measures of inflation expectations and trend productivity growth (Table 4).

\section{B. The role of latent slack}

Recent studies have argued that measured unemployment rates may not accurately capture slack in the United States (with a
Figure 10. Effects on Growth of Compensation per Hour: Country-by-Country Estimation, Oross-Country Dispersion (Percentage points)

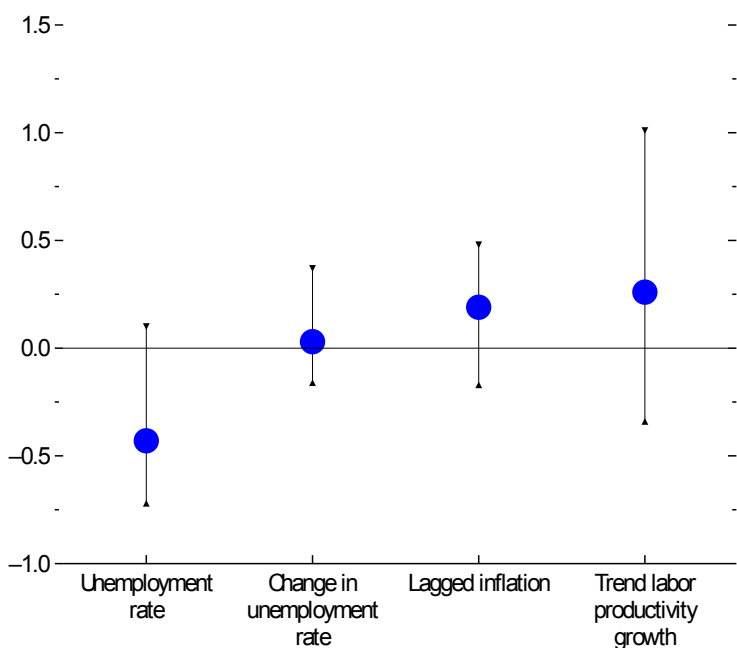

Source: Authors' calculations

Note: The wage variable used is compensation per hour of workers excluding the self-employed. Markers show means of country-by-country estimation coefficients, and lines display corresponding interquartile ranges. Sample excludes Baltic countries. Figure is based on column (8) of Table 3.

\begin{tabular}{|c|c|c|c|c|c|}
\hline & $\begin{array}{c}\text { (1) } \\
\text { Benchmark }^{1}\end{array}$ & $\begin{array}{c}\text { (2) } \\
\text { Alternative } \\
\text { Measure of } \\
\text { Labor Market } \\
\text { Slack }^{3} \\
\end{array}$ & $\begin{array}{c}\text { (3) } \\
\text { Alternative } \\
\text { Measure of } \\
\text { Inflation } \\
\text { Expectations }{ }^{4}\end{array}$ & $\begin{array}{c}\text { (4) } \\
\text { Alternative } \\
\text { Measure of Trend } \\
\text { Productivity } \\
\text { Growth } \\
\end{array}$ & $\begin{array}{c}(5) \\
\text { Restricting the } \\
\text { Coefficient of Trend } \\
\text { Productivity } \\
\text { Growth }^{6} \\
\end{array}$ \\
\hline & $\mathrm{IV}^{2}$ & $\mathrm{IV}^{2}$ & $\mathrm{IV}^{2}$ & $\mathrm{IV}^{2}$ & $\mathrm{IV}^{2}$ \\
\hline Unemployment Rate & $\begin{array}{c}-0.339^{\star \star \star} \\
(0.0291)\end{array}$ & & $\begin{array}{c}-0.220^{\star \star *} \\
(0.0236)\end{array}$ & $\begin{array}{c}-0.347^{\star \star * *} \\
(0.0296)\end{array}$ & $\begin{array}{c}-0.339^{\star \star \star} \\
(0.0287)\end{array}$ \\
\hline Output Gap & & $\begin{array}{l}0.291^{\star * *} \\
(0.0331)\end{array}$ & & & \\
\hline Change in Unemployment Rate & $\begin{array}{c}0.0244 \\
(0.0480)\end{array}$ & $\begin{array}{c}0.0279 \\
(0.0502)\end{array}$ & $\begin{array}{c}-0.0935^{\star \star \star \star} \\
(0.0397)\end{array}$ & $\begin{array}{c}-0.00512 \\
(0.0479)\end{array}$ & $\begin{array}{c}0.0240 \\
(0.0447)\end{array}$ \\
\hline Lagged Inflation & $\begin{array}{c}0.195 \\
(0.120)\end{array}$ & $\begin{array}{c}0.149 \\
(0.128)\end{array}$ & $\begin{array}{l}0.735^{\star \star \star} \\
(0.0594)\end{array}$ & $\begin{array}{c}0.302^{\star \star \star *} \\
(0.117)\end{array}$ & $\begin{array}{l}0.196^{*} \\
(0.108)\end{array}$ \\
\hline Ten-Year Inflation Expectation & & & $\begin{array}{l}0.265^{\star \star \star} \\
(0.0594)\end{array}$ & & \\
\hline Trend Productivity Growth Rate: Five-year ${ }^{7}$ & $\begin{array}{l}0.783^{\star \star \star} \\
(0.0720)\end{array}$ & $\begin{array}{l}0.645^{\star \star \star} \\
(0.0727)\end{array}$ & $\begin{array}{l}0.553^{\star \star *} \\
(0.0634)\end{array}$ & & 0.781 \\
\hline Trend Productivity Growth Rate: Three-year ${ }^{8}$ & & & & $\begin{array}{l}0.410^{\star \star \star} \\
(0.0692)\end{array}$ & \\
\hline First-Stage F-statistics above 10 & yes & yes & yes & yes & yes \\
\hline Country Fixed Effects & yes & yes & yes & yes & yes \\
\hline Year Fixed Effects & no & no & no & no & no \\
\hline Number of Observations & 1,656 & 1,656 & 1,656 & 1,656 & 1,656 \\
\hline$R^{2}$ & 0.406 & 0.369 & 0.379 & 0.396 & 0.284 \\
\hline \multicolumn{6}{|c|}{$\begin{array}{l}\text { Note: Dependent variable }=\text { year-over-year growth rate of compensation per hour of workers excluding the self-employed. Sample is of quarterly } \\
\text { frequency from the first quarter of } 2000 \text { to the fourth quarter of } 2016 \text {. See Table } 1 \text { for countries in the sample. IV }=\text { instrumental variable. Standard } \\
\text { errors in parentheses. }{ }^{*} p<.10 ;{ }^{* \star} p<.05 ;{ }^{* \star \star} p<.01 .\end{array}$} \\
\hline \multicolumn{6}{|c|}{$\begin{array}{l}{ }^{1} \text { The sample size is slightly smaller than that in Table } 1 \text {, as this table ensures the sample size consistency for columns (1) to (5). } \\
{ }^{2} \text { The instrumental variable for lagged inflation is the two-quarter-lagged change in oil price. } \\
{ }^{3} \text { Output gap replaces unemployment rate as the measure of the labor market slack. } \\
{ }^{4} \text { Lagged inflation is replaced by lagged inflation and } 10 \text {-year inflation expectation, with the sum of the two coefficients assumed to be } 1 .\end{array}$} \\
\hline
\end{tabular}

\footnotetext{
${ }^{19}$ The coefficients from the country-by-country specifications are, however, less precisely estimated than the
} panel coefficients due to smaller samples. 
resulting focus on U-6 as a broader measure of slack), some parts of the euro area (ECB 2017), and the United Kingdom (Bank of England 2017). ${ }^{20}{ }^{21}$ Furthermore, to the extent that declining unemployment rates partly reflect workers forced into part-time jobs, increases in such types of employment may overstate the tightening of the labor market. Specifically, these workers may be willing to accept slower increases in wages and, at the same time, may continue to seek full-time employment and open-ended contracts. By doing so, they compete with workers employed under more traditional arrangements and so weigh on their wage growth as well. True labor market slack may therefore be larger than suggested by headline unemployment rates. ${ }^{22}$

Extensions of the baseline approach examine whether the changing nature of employment (as documented in the section on surface healing masking deeper changes in advanced economy labor markets) may have contributed to latent slack in the economy that is not picked up in headline unemployment numbers. The analysis augments the baseline approach with the shares of involuntary part-time employment and temporary contracts) ${ }^{23}$

Tables 5-7 augment the wage Phillips curve specification in Table 3 further with the share of involuntary part-time employment. They also examine robustness to using different measures of wages, and study differences across countries with unemployment rates below, moderately above, and appreciably above 2000-07 averages.

\footnotetext{
${ }^{20} \mathrm{U}-6$ includes the total unemployed, plus all marginally attached workers and total employed part-time for economic reasons as a percent of the civilian labor force plus all marginally attached workers.

${ }^{21}$ The evidence for the United States appears mixed. Krueger (2015) argues that the measured unemployment rate overstates the degree of slack in the United States because long-term unemployed workers have a negligible impact on wage setting. But as the same paper notes, other studies-Aaronson and Jordan (2014) Altig and Higgins (2014), Smith (2014), and Kumar and Orrenius (2016) — do find some evidence on the impact of the long-term-unemployment rate on wage growth, including at the state level.

${ }^{22}$ Aoyagi and Ganelli (2015) study the growing importance of nonregular employment in Japan in recent years. Katz and Krueger (2016) discuss the rise of alternative, flexible work arrangements - temping, contracting, freelancing through short-term gigs - in the United States. They estimate that workers in such arrangements now comprise 16 percent of the US workforce. See also Brainard (2016).

${ }^{23}$ These could be seen as signs of binding constraints on workers (possibly stemming from weak labor demand since the Great Recession), reflecting in part structural developments, though with an important cyclical component. Given that hours per worker also reflect worker preferences, this attribute is not considered here as a measure of latent slack.
} 
Table 5. Estimation of Wage Phillips Curve Augmented with Involuntary Part-Time Employment Share by Country Group

\begin{tabular}{|c|c|c|c|c|c|c|c|c|}
\hline & $\begin{array}{c}(1) \\
\text { Full Sample }\end{array}$ & $\begin{array}{c}\text { (2) } \\
\text { Group A }\end{array}$ & $\begin{array}{c}\text { (3) } \\
\text { Group B }\end{array}$ & $\begin{array}{c}\text { (4) } \\
\text { Group C }\end{array}$ & $\begin{array}{c}\text { (5) } \\
\text { Full Sample } \\
\end{array}$ & $\begin{array}{c}\text { (6) } \\
\text { Group A }\end{array}$ & $\begin{array}{c}\text { (7) } \\
\text { Group B }\end{array}$ & $\begin{array}{c}\text { (8) } \\
\text { Group C }\end{array}$ \\
\hline & OLS & OLS & OLS & OLS & $\mathrm{IV}^{1}$ & $\mathrm{IV}^{1}$ & $\mathrm{IV}^{1}$ & $\mathrm{IV}^{1}$ \\
\hline Involuntary Part-Time Employment Share & $\begin{array}{l}-0.177^{\star *} \\
(0.0830)\end{array}$ & $\begin{array}{l}-0.503^{*} \\
(0.274)\end{array}$ & $\begin{array}{c}-0.336^{\star *} \\
(0.139)\end{array}$ & $\begin{array}{l}0.0159 \\
(0.124)\end{array}$ & $\begin{array}{l}-0.275^{* * *} \\
(0.0829)\end{array}$ & $\begin{array}{c}-0.653^{\star *} \\
(0.294)\end{array}$ & $\begin{array}{l}-0.291^{*} \\
(0.154)\end{array}$ & $\begin{array}{l}-0.186^{*} \\
(0.101)\end{array}$ \\
\hline Unemployment Rate & $\begin{array}{c}-0.187^{* * *} \\
(0.0445)\end{array}$ & $\begin{array}{l}-0.0178 \\
(0.128)\end{array}$ & $\begin{array}{c}-0.00699 \\
(0.186)\end{array}$ & $\begin{array}{c}-0.280^{* * *} \\
(0.0686)\end{array}$ & $\begin{array}{c}-0.182^{* * *} \\
(0.0438)\end{array}$ & $\begin{array}{l}0.0855 \\
(0.146)\end{array}$ & $\begin{array}{l}-0.284 \\
(0.186)\end{array}$ & $\begin{array}{c}-0.395^{\star * *} \\
(0.0722)\end{array}$ \\
\hline Change in Unemployment Rate & $\begin{array}{c}-0.349^{* * *} \\
(0.0960)\end{array}$ & $\begin{array}{c}-0.690^{* * *} \\
(0.244)\end{array}$ & $\begin{array}{c}-0.609^{* *} \\
(0.271)\end{array}$ & $\begin{array}{l}-0.128 \\
(0.129)\end{array}$ & $\begin{array}{c}-0.263^{* \star *} \\
(0.0887)\end{array}$ & $\begin{array}{c}-0.449^{* *} \\
(0.181)\end{array}$ & $\begin{array}{c}-0.830^{* * *} \\
(0.247)\end{array}$ & $\begin{array}{l}0.0821 \\
(0.117)\end{array}$ \\
\hline Lagged Inflation & $\begin{array}{l}0.193^{\text {***}} \\
(0.0728)\end{array}$ & $\begin{array}{c}0.378^{* * *} \\
(0.129)\end{array}$ & $\begin{array}{l}-0.183 \\
(0.124)\end{array}$ & $\begin{array}{c}0.156 \\
(0.206)\end{array}$ & $\begin{array}{l}0.300^{*} \\
(0.164)\end{array}$ & $\begin{array}{c}0.287 \\
(0.282)\end{array}$ & $\begin{array}{c}0.397 \\
(0.248)\end{array}$ & $\begin{array}{l}-0.279 \\
(0.292)\end{array}$ \\
\hline Trend Productivity Growth Rate ${ }^{2}$ & $\begin{array}{c}0.456^{\star \star *} \\
(0.112)\end{array}$ & $\begin{array}{l}0.634^{*} \\
(0.348)\end{array}$ & $\begin{array}{l}-0.131 \\
(0.189)\end{array}$ & $\begin{array}{c}0.699^{* * *} \\
(0.170)\end{array}$ & $\begin{array}{c}0.624^{\star * \star} \\
(0.106)\end{array}$ & $\begin{array}{c}0.763^{* \star \star} \\
(0.223)\end{array}$ & $\begin{array}{c}0.00955 \\
(0.176)\end{array}$ & $\begin{array}{c}0.986^{\star \star *} \\
(0.170)\end{array}$ \\
\hline $\begin{array}{l}\text { First-Stage F-statistics above } 10 \\
\text { Country Fixed Effects }\end{array}$ & $\begin{array}{l}\text { yes } \\
\text { yes }\end{array}$ & $\begin{array}{l}\text { yes } \\
\text { yes }\end{array}$ & $\begin{array}{l}\text { yes } \\
\text { yes }\end{array}$ & $\begin{array}{l}\text { yes } \\
\text { yes }\end{array}$ & $\begin{array}{l}\text { yes } \\
\text { yes }\end{array}$ & $\begin{array}{l}\text { yes } \\
\text { yes }\end{array}$ & $\begin{array}{l}\text { yes } \\
\text { yes }\end{array}$ & $\begin{array}{l}\text { yes } \\
\text { yes }\end{array}$ \\
\hline Year Fixed Effects & yes & yes & yes & yes & no & no & no & no \\
\hline $\begin{array}{l}\text { Number of Observations } \\
R^{2}\end{array}$ & $\begin{array}{c}411 \\
0.610\end{array}$ & $\begin{array}{c}117 \\
0.709\end{array}$ & $\begin{array}{c}146 \\
0.649\end{array}$ & $\begin{array}{c}148 \\
0.723\end{array}$ & $\begin{array}{c}411 \\
0.577\end{array}$ & $\begin{array}{c}117 \\
0.652\end{array}$ & $\begin{array}{c}146 \\
0.458\end{array}$ & $\begin{array}{c}148 \\
0.660\end{array}$ \\
\hline $\begin{array}{l}\text { Note: Dependent variable = annual growth } \\
\text { to } 2016 \text {. See Table } 1 \text { for countries in the } f \\
\text { Country groups are divided by comparing } \\
\text { Republic, Germany, Japan, Israel, Slovak } \\
\text { Australia, Austria, Belgium, Canada, Switz } \\
\text { Denmark, Spain, France, Greece, Ireland } \\
\text { in parentheses. * } p<.10 ;{ }^{* *} p<.05 \text {; }{ }^{* \star} p \\
\text { 'The instrumental variable for lagged infla }\end{array}$ & $\begin{array}{l}\text { Remublic, Unite } \\
\text { erland, Finland, } \\
\text { Italy, Netherlan } \\
.01 \text {. } \\
\text { ion is the two-q }\end{array}$ & $\begin{array}{l}\text { Kingdom, a } \\
\text { Kindand, Nor } \\
\text { Is, Portugal, } \\
\text { arter-lagged }\end{array}$ & $\begin{array}{l}2000-07 \\
\text { United St } \\
\text { dd Slovenia }\end{array}$ & $\begin{array}{l}\text { rage. Grou } \\
\text { Group B } \\
=\text { instrume C } \\
\text { ce. }\end{array}$ & $\begin{array}{l}\text { (2016 unemplo } \\
6 \text { unemploym } \\
16 \text { unemploym } \\
\text { I variable. OLS }\end{array}$ & $\begin{array}{l}\text { ment lowe } \\
\text { it moderate } \\
\text { nt apprecia } \\
\text { ordinary le }\end{array}$ & $\begin{array}{l}\text { tan } 2000-07 \\
\text { higher than } \\
\text { higher than } \\
\text { t squres. St }\end{array}$ & $\begin{array}{l}\text { from } 2000 \\
\text { nt share. } \\
\text { Czech } \\
00-07) \text { : } \\
000-07) \text { : } \\
\text { dard errors }\end{array}$ \\
\hline
\end{tabular}

Table 6. Estimation of Wage Phillips Curve Augmented with Involuntary Part-Time Employment Share: Full Sample and Countries with Unemployment Rates Lower than 2000-07 Average

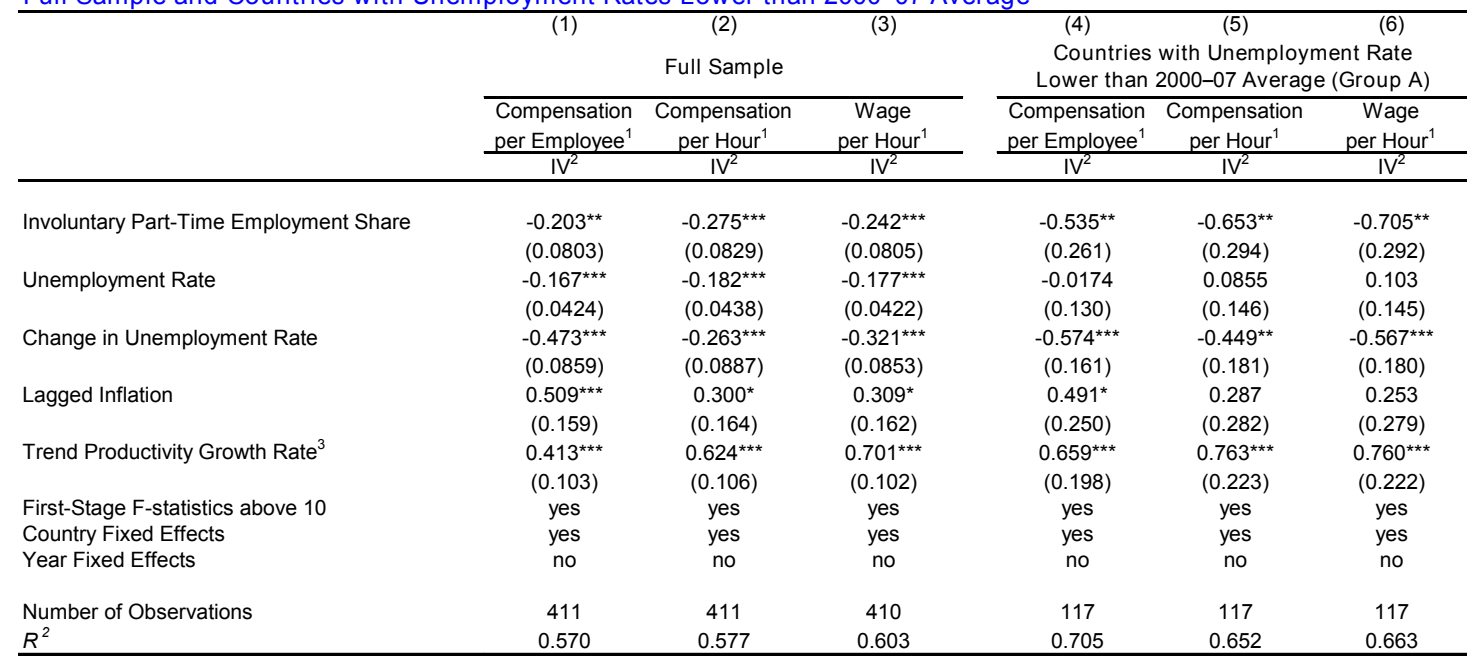

Note: Sample is of annual frequency from 2000 to 2016 . See the notes in Table 5 for countries in the full sample and group A. IV $=$ instrumental variable. Standard errors in parentheses. ${ }^{*} p<.10 ;{ }^{* *} p<.05 ;{ }^{* *} p<.01$

${ }^{1}$ The dependent variable of the regression, defined as annual growth rates.

${ }^{2}$ The instrumental variable for lagged inflation is the two-quarter-lagged change in oil price.

${ }^{3}$ Five-year trailing average of the labor productivity growth rate. 


\begin{tabular}{|c|c|c|c|c|c|c|}
\hline \multicolumn{7}{|c|}{$(2)$} \\
\hline & \multicolumn{3}{|c|}{$\begin{array}{l}\text { Countries with Unemployment Rates Moderately } \\
\text { Higher than 2000-07 Average (Group B) }\end{array}$} & \multicolumn{3}{|c|}{$\begin{array}{c}\text { Countries with Unemployment Rates Appreciably } \\
\text { Higher than 2000-07 Average (Group C) }\end{array}$} \\
\hline & $\begin{array}{l}\text { Compensation } \\
\text { per Employee }\end{array}$ & $\begin{array}{l}\text { Compensation } \\
\text { per Hour }{ }^{1}\end{array}$ & $\begin{array}{c}\text { Wage } \\
\text { per Hour }{ }^{1}\end{array}$ & $\begin{array}{l}\text { Compensation } \\
\text { per Employee }\end{array}$ & $\begin{array}{l}\text { Compensation } \\
\text { per Hour }{ }^{1}\end{array}$ & $\begin{array}{c}\text { Wage } \\
\text { per Hour }\end{array}$ \\
\hline & $\mathrm{IV}^{2}$ & $\mathrm{IV}^{2}$ & $\mathrm{IV}^{2}$ & $\mathrm{IV}^{2}$ & $\mathrm{IV}^{2}$ & $\mathrm{IV}^{2}$ \\
\hline \multirow[t]{2}{*}{ Involuntary Part-Time Employment Share } & -0.221 & $-0.291^{*}$ & -0.110 & $-0.157^{\star}$ & $-0.186^{*}$ & $-0.235^{\star \star}$ \\
\hline & $(0.147)$ & $(0.154)$ & $(0.147)$ & $(0.0923)$ & $(0.101)$ & $(0.105)$ \\
\hline \multirow[t]{2}{*}{ Unemployment Rate } & -0.203 & -0.284 & -0.147 & $-0.358^{\star \star *}$ & $-0.395^{\star \star *}$ & $-0.375^{\star \star *}$ \\
\hline & $(0.177)$ & $(0.186)$ & $(0.187)$ & $(0.0663)$ & $(0.0722)$ & $(0.0751)$ \\
\hline \multirow[t]{2}{*}{ Change in Unemployment Rate } & $-1.429^{\star \star \star}$ & $-0.830^{\star \star \star}$ & $-0.743^{\star \star \star}$ & -0.0369 & 0.0821 & -0.0381 \\
\hline & $(0.235)$ & $(0.247)$ & $(0.241)$ & $(0.107)$ & $(0.117)$ & $(0.121)$ \\
\hline \multirow[t]{2}{*}{ Lagged Inflation } & $0.522^{\star \star}$ & 0.397 & $0.780^{\star \star \star}$ & -0.126 & -0.279 & -0.369 \\
\hline & $(0.236)$ & $(0.248)$ & $(0.259)$ & $(0.268)$ & $(0.292)$ & $(0.304)$ \\
\hline \multirow[t]{2}{*}{ Trend Productivity Growth Rate ${ }^{3}$} & -0.183 & 0.00955 & 0.0518 & $0.834^{\star \star \star}$ & $0.986^{\star \star \star}$ & $1.082^{\star \star \star}$ \\
\hline & $(0.168)$ & $(0.176)$ & $(0.167)$ & $(0.156)$ & $(0.170)$ & $(0.177)$ \\
\hline First-Stage F-statistics above 10 & yes & yes & yes & yes & yes & yes \\
\hline Country Fixed Effects & yes & yes & yes & yes & yes & yes \\
\hline Year Fixed Effects & no & no & no & no & no & no \\
\hline Number of Observations & 146 & 146 & 145 & 148 & 148 & 148 \\
\hline$R^{2}$ & 0.487 & 0.458 & 0.389 & 0.681 & 0.660 & 0.652 \\
\hline \multicolumn{7}{|c|}{$\begin{array}{l}\text { Note: Sample is of annual frequency from } 2000 \text { to } 2016 \text {. See the notes in Table } 5 \text { for countries in groups B and C. IV = instrumental variable. Standard errors in } \\
\text { parentheses. }{ }^{\star} p<.10 ;{ }^{\star \star} p<.05 ;{ }^{\star \star} p<.01 \text {. }\end{array}$} \\
\hline \multicolumn{7}{|c|}{${ }^{1}$ The dependent variable of the regression, defined as annual growth rates. } \\
\hline \multicolumn{7}{|c|}{${ }^{2}$ The instrumental variable for lagged inflation is the two-quarter-lagged change in oil price. } \\
\hline${ }^{3}$ Five-year trailing average of the labor pro & activity growth rate. & & & & & \\
\hline
\end{tabular}

A higher share of involuntary part-time employment is associated with lower wage growth, even after controlling for the influence of the variables discussed previously. Across all countries, on average, a 1 percentage point increase in the involuntary part-time employment share is associated with a 0.3 percentage point decline in nominal wage growth. To allow for the possibility that coefficients might vary across countries that have had different degrees of labor market tightening since the crisis, the regressions are also run separately for three subgroups. The effect is more pronounced in countries where the unemployment rate is below pre-Great Recession averages. Within this group of countries, a 1 percentage point increase in the involuntary part-time employment share is associated with a 0.7 percentage point decline in wage growth. The estimated effect is only 0.2 percentage point for countries with unemployment appreciably above the pre-Great Recession averages. Though the point estimates are different for these subsamples, these differences are not statistically significant (Figure 11 depicts the coefficients shown in Table 5, columns 5-8).

\section{Alternative wage measures}

Robustness tests reported in Table 6 and 7 examine different choices of wage measures as the dependent variable in equation 2 for the full sample and for the three sub-groups - aggregate compensation divided by total employees (compensation per employee), aggregate wage bill divided by total employees (wage per employee), aggregate compensation divided by total hours (compensation per hour), and aggregate wage bill divided by total hours (wage per hour, which includes aggregate social contributions of employers). Figure 12 plots the coefficients on involuntary part-time employment share from the different regressions that use alternative measures for wages. The pattern is broadly similar to the baseline. 
Figure 11. Effects of Involuntary Part-Time Employment on Growth of Compensation per Hour, 2000-16

(Percentage points)

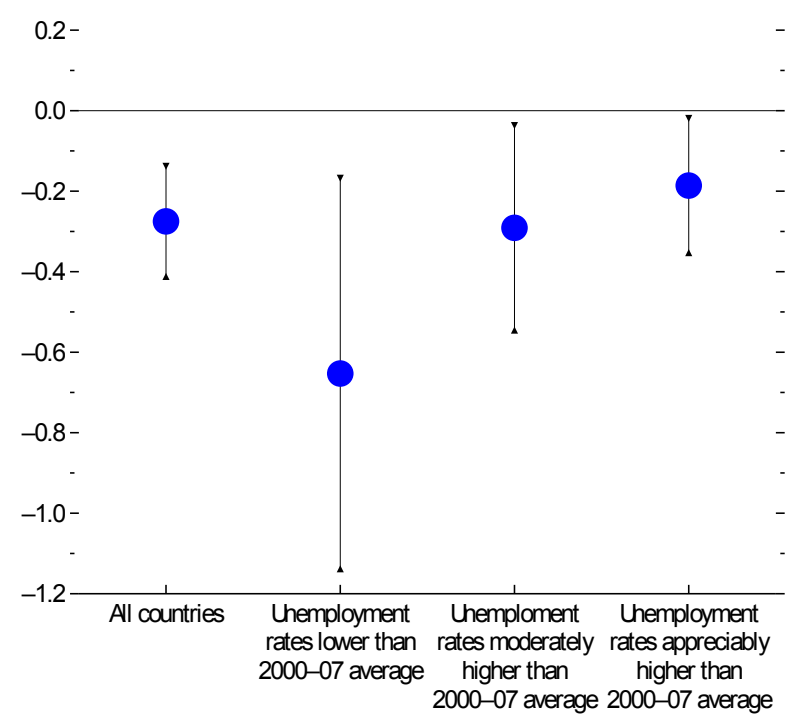

Source: Authors' calculations.

Note: The wage variable used is compensation per hour of workers excluding the self-employed. Markers show estimated coefficients, and lines display 90 percent confidence intervals. Involuntary part-time workers are those working less than 30 hours a week because they could not find a full-time position. The involuntary part-time employment share is calculated as the total number of involuntary parttime workers divided by total employment. Countries with unemployment rates lower than the 2000-07 average are CZF DEU, GBR ISR JPN SYK and USA: countries with unemployment rates moderately higher than the 2000-07 average are those with increases below the median of all countries with unemployment rate increases and comprise AUS, AUT, BE, CAN CFE FN, ISL, NCR and SWE countries with unemployment rates appreciably higher than the 2000-07 average are those with increases above the median of all countries with unemployment rate increases and comprise DNK ESP, RA GRC, IRL, ITA ND, PRT, and SW Abbreviations in note use International Organization for Standardization (ISO) country codes. Figure is based on columns (5) to (8) of Table 5.

In contrast to the finding that involuntary parttime employment has weighed on nominal wage growth, the analysis does not detect a role for temporary contracts in affecting wage dynamics (results available upon request). In general, the temporary contract share of employment does not have a statistically significant effect on aggregate wages for the whole sample or different subgroups. This could in part reflect measurement problems for this variable; to ensure cross-country comparability, the analysis uses a measure that does not contain information on regular versus nonregular contracts, but rather one that adheres to a legal definition of temporariness.
Figure 12. Effects of Involuntary Part-Time Employment on Compensation and Wages, 2000-16 (Percentage points)
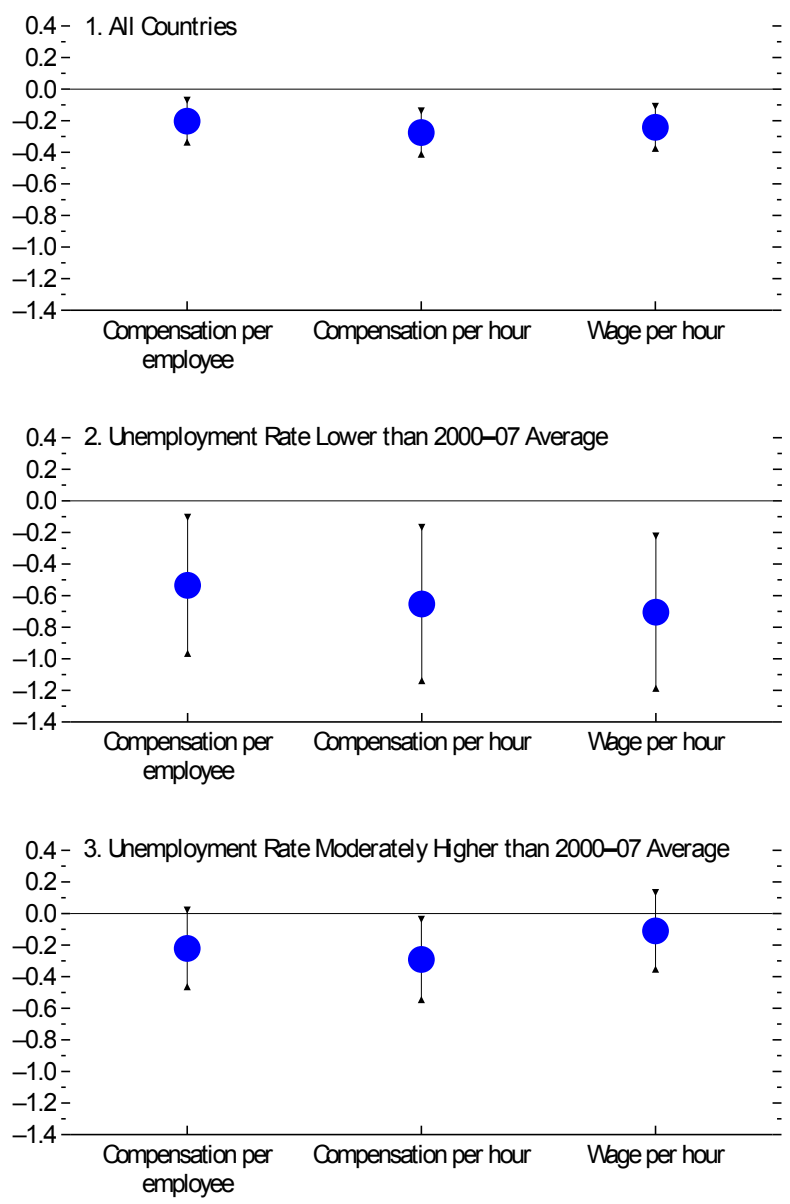

0.4 - 4. Unemployment Rate Appreciably Hgher than 2000-07 Average $0.2-$

0.0

$-0.2^{-}$

$-0.4-$

$-0.6-$

$-0.8$

$-1.0-$

$-1.2=$

$-1.4$

Compensation per Compensation per hour Wage per hour
employee

Source: Authors' calculations.

Note: Markers show estimated coefficients, and lines display 90 percent confidence intervals. Involuntary part-time workers are those working less than 30 hours a week because they could not find a full-time position. The involuntary part-time employment share is calculated as the total number of involuntary parttime workers divided by total employment. Groups are as defined in Table 5. Figure is based on Tables 6 and 7 . 


\section{Contributions to Changes in Nominal Wage Growth}

Figure 13. Decomposition of Wage Dynamics, 2000-16 (Percentage point change relative to 2000-07 average)

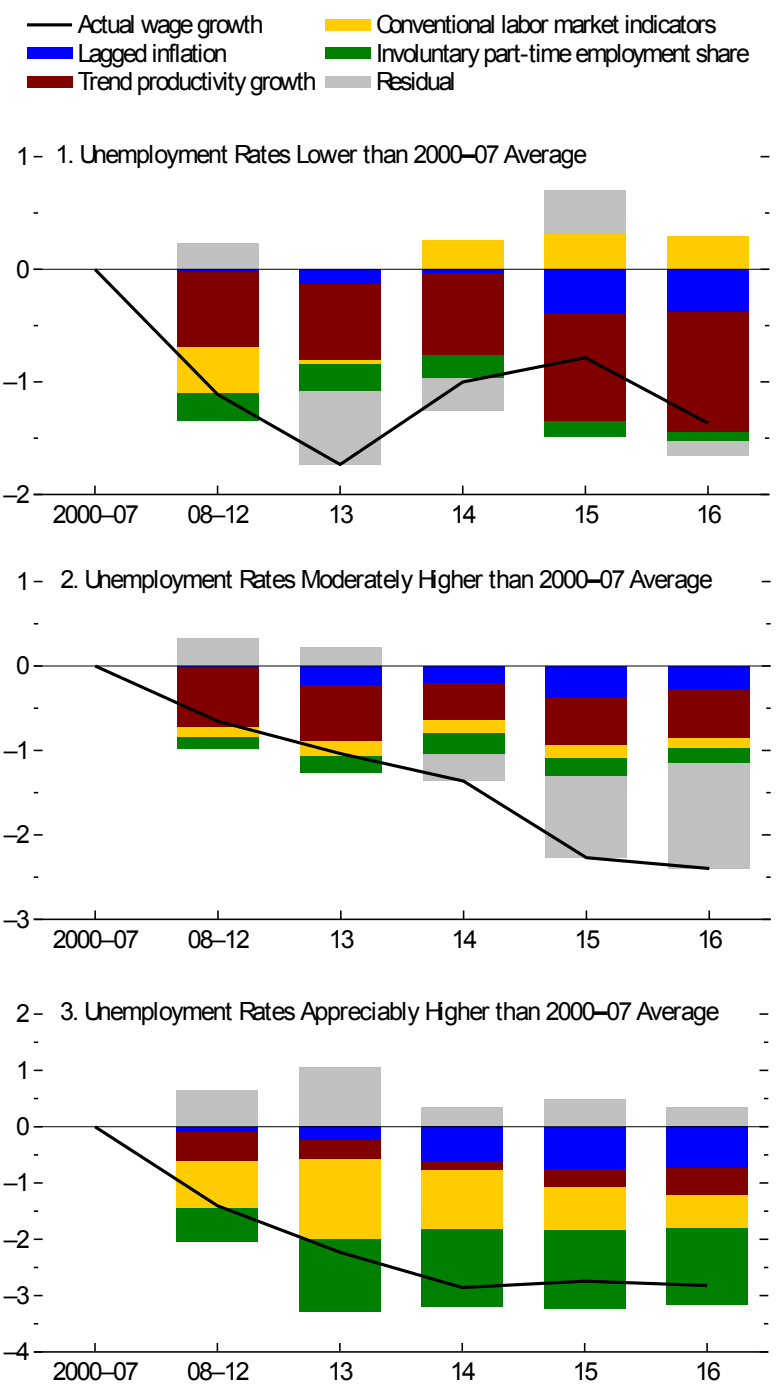

Source: Authors' calculations.

Note: The wage variable used is compensation per hour of workers excluding the self-employed. Involuntary part-time workers are those working less than 30 hours a week because they could not find a full-time position. The involuntary part-time employment share is calculated as the total number of involuntary part-time workers divided by total employment. Groups are as defined in Table 5. The decomposition is based on the coefficients reported in column (5) of Table 5 and is weighted by GDP at market exchange rates across countries.
Putting the influences of slack, past inflation, and trend productivity growth together, Figure 13 examines the contributions of these factors to changes in average nominal wage growth since 2008 relative to $2000-07$. For countries with unemployment rates below 2000-07 averages, about two-thirds of the observed decline in nominal wage growth can be explained by slower trend productivity growth - an effect that is larger in 2015-16 than in previous years (given the recent decline in trend productivity growth for this group). Lower slack (captured here using the conventional labor market indicators: the unemployment rate and its change) would have acted to increase nominal wage growth since 2014. However, involuntary part-time employment continues to weigh on nominal wage growth (Figure 13, panel 1). In contrast, in countries with unemployment rates still above what they were before the crisis, conventional measures of labor market slack can explain about half of the slowdown in nominal wage growth since 2007, with involuntary part-time employment further weighing on wages (although part-time employment, even if involuntary, may have supported labor force participation and facilitated stronger engagement with the workplace than the alternative of unemployment). Productivity growth plays a smaller role, possibly as it was already slow in the years before the crisis (Figure 13, panels 2 and 3). Figure 14 shows a decomposition similar to that in Figure 13 , based on a regression with year fixed effects. The relative importance of the different drivers (slack versus productivity) shown in Figure 12 remains valid when year fixed effects are included. 
Figure 14. Decomposition of Wage Dynamics, 2000-16 (Percentage point change relative to 2000-07 average)

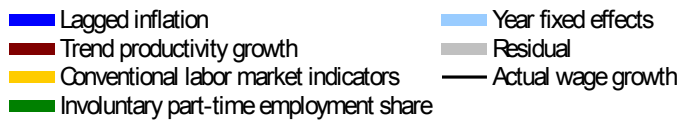

2- 1. Uhemployment Rates Lower than 2000-07 Average
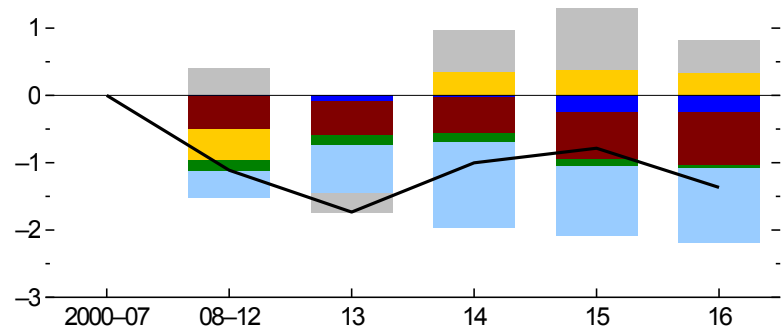

1- 2. Unemployment Rates Moderately Hgher than 2000-07 Average
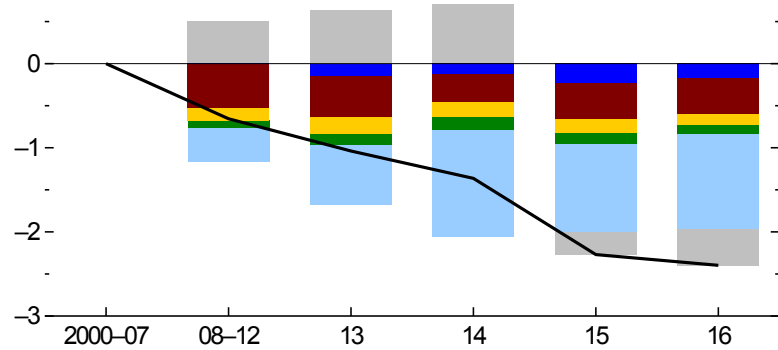

2- 3. Uhemployment Rates Appreciably Hgher than 2000-07 Average

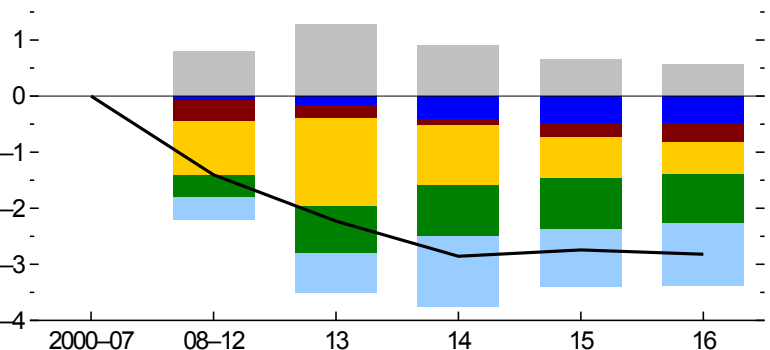

Source: Authors' calculations

Note: The wage variable used is compensation per hour of workers excluding the self-employed. Involuntary part-time workers are those working less than 30 hours a week because they could not find a full-time position. The involuntary part-time employment share is calculated as the total number of involuntary part-time workers divided by total employment. Groups are as defined in Table 5 The decomposition is based on the coefficients reported in column (1) of Table 5 and is weighted by GDP at market exchange rates across countries.

However, as illustrated in Figure 15, even beyond these factors, there is a negative residual after 2009, and especially during 2014-16. The residual could be picking up the effects of increased integration that make external conditions matter more and, in general, weigh on wage growth. Its increasing importance after the Great Recession and after

\section{Common Components}

The domestic conditions driving wages (such as unemployment) could have a significant common component, given economic linkages between countries as well as the common influence of global factors. In addition, domestic conditions in one country could have direct spillover effects on wage setting in others. For instance, relative wage weakness in one country could put downward pressure on wages in other countries, given the threat of production relocation toward lower-cost destinations. These common factors would be picked up by statistically significant time effects in the ordinary least squares regressions. The estimated year fixed effects tend to be correlated with advanced economy averages of lagged inflation, trend productivity growth, unemployment, and involuntary part-time employment. These forces together can explain over 70 percent of the total variation in the estimated year fixed effects.

Figure 15. Year Fixed Effects and Common Drivers, 2000-16 (Index)

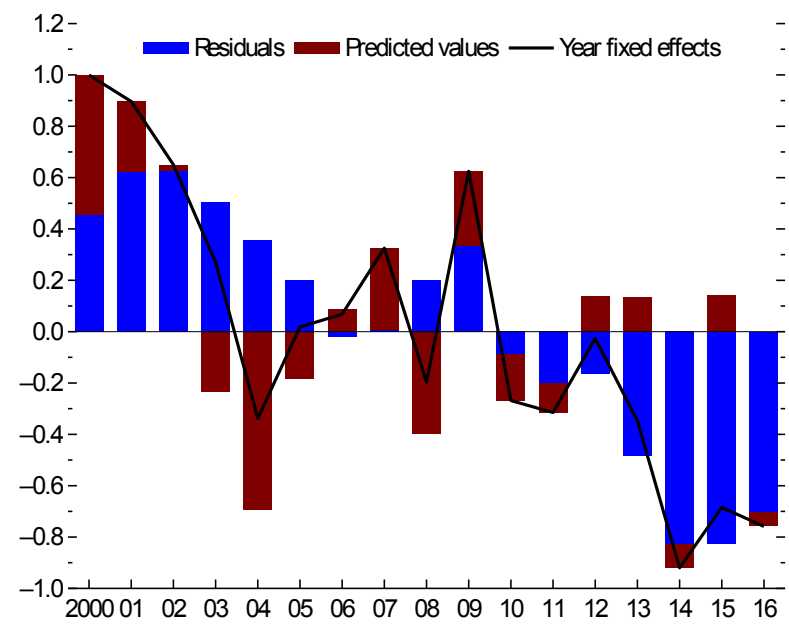

Source: Authors' calculations.

Note: Year fixed effects are based on the panel ordinary least squares regression in column (1) of Table 5. Residuals are from a regression of these year fixed effects on advanced economy averages of the drivers shown in Figure 13 and a constant. Year fixed effects and predicted values are subsequently renormalized such that year fixed effects over 2000-16 average to zero. 
the euro area sovereign debt crisis could point to downward pressure on wage demands as a result of synchronized recessions, and, in some cases, policy measures to slow wage growth and improve competitiveness. These findings thus corroborate the earlier findings on the importance of slack and lagged inflation on wage growth and also point to the effects of additional common external factors.

\section{E. Underlying Drivers}

Subdued nominal wage growth and changes in the nature of employment have taken place in an environment of declining potential growth, changes to global production processes related to automation and trade integration, and changes in labor market institutions (Figures 16 and 17).

The effects of secular drivers on job attributes are examined using a cross-country panel regression of 36 countries from 2000 to 2016, including country and year fixed effects, and controlling for the output gap. In this analysis, the share of involuntary part-time workers at the country level is the main dependent variable. Potential secular drivers include measures of worker bargaining power (proxied by the five-year change in the union density rate), the five-year change in the share of employment in the services sector, technological change (proxied by the five-year change in the relative price of investment), growth expectations, and global value chain integration (proxied by the five-year change in foreign value added as a percent of exports).

\begin{tabular}{|c|c|c|c|c|c|c|c|c|c|}
\hline & $\begin{array}{l}(1) \\
\mathrm{IV}^{1} \\
\end{array}$ & $\begin{array}{l}(2) \\
\mathrm{IV}^{1} \\
\end{array}$ & $\begin{array}{l}(3) \\
\mathrm{IV}^{1} \\
\end{array}$ & $\begin{array}{l}(4) \\
I^{1} \\
\end{array}$ & $\begin{array}{l}(5) \\
I^{1} \\
\end{array}$ & $\begin{array}{l}(6) \\
\mathrm{IV}^{1} \\
\end{array}$ & $\begin{array}{l}(7) \\
\mathrm{IV}^{1}\end{array}$ & $\begin{array}{l}(8) \\
I^{1} \\
\end{array}$ & $\begin{array}{l}\text { (9) } \\
\mathrm{IV}^{1}\end{array}$ \\
\hline Involuntary Part-Time Employment Share & $\begin{array}{l}-0.275^{\star \star *} \\
(0.0829)\end{array}$ & $\begin{array}{l}-0.306^{\star \star *} \\
(0.0947)\end{array}$ & $\begin{array}{l}-0.192^{\star *} \\
(0.0845)\end{array}$ & $\begin{array}{l}-0.200^{* *} \\
(0.0976)\end{array}$ & $\begin{array}{l}-0.166^{*} \\
(0.0977)\end{array}$ & $\begin{array}{l}-0.225^{\star \star \star} \\
(0.0794)\end{array}$ & $\begin{array}{l}-0.272^{\star \star \star} \\
(0.0830)\end{array}$ & $\begin{array}{r}-0.0840 \\
(0.133)\end{array}$ & $\begin{array}{r}-0.0570 \\
(0.125)\end{array}$ \\
\hline Unemployment Rate & $\begin{array}{c}-0.182^{* * *} \\
(0.0438)\end{array}$ & $\begin{array}{c}-0.226^{\star \star \star} \\
(0.0556)\end{array}$ & $\begin{array}{c}-0.211^{\star \star \star} \\
(0.0492)\end{array}$ & $\begin{array}{c}-0.293^{\star \star \star} \\
(0.0688)\end{array}$ & $\begin{array}{c}-0.365^{\star \star \star} \\
(0.0590)\end{array}$ & $\begin{array}{c}-0.199^{\star \star \star} \\
(0.0444)\end{array}$ & $\begin{array}{c}-0.177^{\star \star \star} \\
(0.0446)\end{array}$ & $\begin{array}{c}-0.333^{\star \star \star} \\
(0.0948)\end{array}$ & $\begin{array}{c}-0.362^{\star \star \star} \\
(0.0902)\end{array}$ \\
\hline Change in Unemployment Rate & $\begin{array}{c}-0.263^{* * *} \\
(0.0887)\end{array}$ & $\begin{array}{l}-0.225^{\star \star} \\
(0.0969)\end{array}$ & $\begin{array}{c}-0.137 \\
(0.0833)\end{array}$ & $\begin{array}{c}-0.284^{\star \star \star} \\
(0.109)\end{array}$ & $\begin{array}{l}-0.0325 \\
(0.0887)\end{array}$ & $\begin{array}{c}-0.247^{\star \star \star} \\
(0.0893)\end{array}$ & $\begin{array}{c}-0.267^{\star \star \star} \\
(0.0887)\end{array}$ & $\begin{array}{c}-0.295^{\star \star} \\
(0.130)\end{array}$ & $\begin{array}{c}-0.334^{\star \star \star} \\
(0.123)\end{array}$ \\
\hline Lagged Inflation & $\begin{array}{c}0.300^{*} \\
(0.164)\end{array}$ & $\begin{array}{c}-0.0452 \\
(0.280)\end{array}$ & $\begin{array}{c}0.00644 \\
(0.197)\end{array}$ & $\begin{array}{l}-0.380 \\
(0.311)\end{array}$ & $\begin{array}{l}-0.236 \\
(0.206)\end{array}$ & $\begin{array}{c}0.199 \\
(0.186)\end{array}$ & $\begin{array}{l}0.308^{*} \\
(0.164)\end{array}$ & $\begin{array}{l}-0.432 \\
(0.332)\end{array}$ & $\begin{array}{l}-0.540 \\
(0.327)\end{array}$ \\
\hline Trend Productivity Growth Rate & $\begin{array}{c}0.624^{\star \star *} \\
(0.106)\end{array}$ & $\begin{array}{c}0.720^{\star \star *} \\
(0.118)\end{array}$ & $\begin{array}{c}0.845^{\star \star \star} \\
(0.109)\end{array}$ & $\begin{array}{c}0.497^{\star \star \star} \\
(0.123)\end{array}$ & $\begin{array}{c}0.594^{\star \star *} \\
(0.117)\end{array}$ & $\begin{array}{c}0.570^{\star \star \star *} \\
(0.101)\end{array}$ & $\begin{array}{c}0.628^{\star \star *} \\
(0.107)\end{array}$ & $\begin{array}{c}0.231 \\
(0.168)\end{array}$ & $\begin{array}{l}0.325^{\star \star} \\
(0.156)\end{array}$ \\
\hline $\begin{array}{l}\text { Change in Foreign Value Added } \\
\text { as a Share of Exports } \\
\end{array}$ & & $\begin{array}{l}0.0944^{* *} \\
(0.0424)\end{array}$ & & & & & & & \\
\hline Change in the Relative Price of Investment $t^{2}$ & & & $\begin{array}{l}0.114^{\star \star \star} \\
(0.0302)\end{array}$ & & & & & & \\
\hline Change in the Union Density Rate ${ }^{2}$ & & & & $\begin{array}{l}-0.330^{\star * \star} \\
(0.0774)\end{array}$ & & & & & $\begin{array}{l}-0.340^{* \star *} \\
(0.0774)\end{array}$ \\
\hline $\begin{array}{l}\text { Change in Individual and Collective } \\
\text { Dismissal Regulation }{ }^{2}\end{array}$ & & & & & $\begin{array}{l}-0.259 \\
(0.918)\end{array}$ & & & & \\
\hline Expected Growth & & & & & & $\begin{array}{l}0.459^{* *} \\
(0.180)\end{array}$ & & & \\
\hline $\begin{array}{l}\text { Change in the Share of Service Sector } \\
\text { Workers }\end{array}$ & & & & & & & $\begin{array}{l}-0.0194 \\
(0.0327)\end{array}$ & & \\
\hline Union Density Rate (Level) & & & & & & & & $\begin{array}{l}0.322^{\star \star *} \\
(0.0836)\end{array}$ & $\begin{array}{l}0.186^{\star \star \star} \\
(0.0678)\end{array}$ \\
\hline First-Stage F-statistics above 10 & yes & yes & yes & yes & yes & yes & yes & yes & yes \\
\hline Country Fixed Effects & yes & yes & yes & yes & yes & yes & yes & yes & yes \\
\hline Year Fixed Effects & no & no & no & no & no & no & no & no & no \\
\hline Number of Observations & 411 & 361 & 316 & 288 & 247 & 411 & 411 & 267 & 264 \\
\hline$R^{2}$ & 0.577 & 0.561 & 0.596 & 0.590 & 0.603 & 0.589 & 0.578 & 0.501 & 0.567 \\
\hline
\end{tabular}


Table 8 augments the wage Phillips curve with secular drivers. Because wage growth rates were volatile during the Great Recession, Table 9 examines robustness to excluding the years 2008 and 2009.

\begin{tabular}{|c|c|c|c|c|c|c|c|c|c|}
\hline & $\begin{array}{l}(1) \\
I^{1} \\
\end{array}$ & $\begin{array}{l}(2) \\
\mathrm{IV}^{1} \\
\end{array}$ & $\begin{array}{l}(3) \\
I^{1} \\
\end{array}$ & $\begin{array}{l}(4) \\
I^{1} \\
\end{array}$ & $\begin{array}{l}(5) \\
\text { IV }^{1} \\
\end{array}$ & $\begin{array}{l}(6) \\
I^{1} \\
\end{array}$ & $\begin{array}{l}(7) \\
\mathrm{IV}^{1} \\
\end{array}$ & $\begin{array}{l}(8) \\
I^{1}\end{array}$ & $\begin{array}{l}(9) \\
\text { IV }^{1}\end{array}$ \\
\hline Involuntary Part-Time Employment Share & $\begin{array}{l}-0.213^{\star \star} \\
(0.0912)\end{array}$ & $\begin{array}{l}-0.227 \\
(0.139)\end{array}$ & $\begin{array}{l}-0.168^{\star} \\
(0.102)\end{array}$ & $\begin{array}{l}-0.215^{\star} \\
(0.123)\end{array}$ & $\begin{array}{l}-0.193 \\
(0.131)\end{array}$ & $\begin{array}{l}-0.173^{\star \star} \\
(0.0862)\end{array}$ & $\begin{array}{l}-0.205^{\star \star} \\
(0.0913)\end{array}$ & $\begin{array}{l}-0.212 \\
(0.198)\end{array}$ & $\begin{array}{l}-0.169 \\
(0.178)\end{array}$ \\
\hline Unemployment Rate & $\begin{array}{c}-0.174^{\star \star \star} \\
(0.0428)\end{array}$ & $\begin{array}{l}-0.205^{\star \star \star} \\
(0.0657)\end{array}$ & $\begin{array}{c}-0.186^{\star \star \star} \\
(0.0549)\end{array}$ & $\begin{array}{c}-0.301^{\star \star \star} \\
(0.105)\end{array}$ & $\begin{array}{l}-0.319^{* \star *} \\
(0.0768)\end{array}$ & $\begin{array}{l}-0.196^{\star \star \star} \\
(0.0446)\end{array}$ & $\begin{array}{l}-0.162^{\star \star \star} \\
(0.0435)\end{array}$ & $\begin{array}{l}-0.367 \\
(0.230)\end{array}$ & $\begin{array}{l}-0.380^{*} \\
(0.227)\end{array}$ \\
\hline Change in Unemployment Rate & $\begin{array}{c}-0.400^{\star \star \star} \\
(0.118)\end{array}$ & $\begin{array}{l}-0.321^{*} \\
(0.183)\end{array}$ & $\begin{array}{l}-0.280^{\star *} \\
(0.131)\end{array}$ & $\begin{array}{l}-0.308^{*} \\
(0.168)\end{array}$ & $\begin{array}{l}-0.129 \\
(0.152)\end{array}$ & $\begin{array}{l}-0.352^{\star \star \star} \\
(0.127)\end{array}$ & $\begin{array}{l}-0.406^{* \star \star} \\
(0.118)\end{array}$ & $\begin{array}{l}-0.495^{\star \star} \\
(0.229)\end{array}$ & $\begin{array}{l}-0.507^{\prime *} \\
(0.213)\end{array}$ \\
\hline Lagged Inflation & $\begin{array}{l}0.502^{\star \star} \\
(0.208)\end{array}$ & $\begin{array}{c}0.351 \\
(0.598)\end{array}$ & $\begin{array}{c}0.180 \\
(0.346)\end{array}$ & $\begin{array}{l}-0.583 \\
(1.107)\end{array}$ & $\begin{array}{l}-0.254 \\
(0.677)\end{array}$ & $\begin{array}{c}0.354 \\
(0.251)\end{array}$ & $\begin{array}{l}0.520^{\star \star} \\
(0.207)\end{array}$ & $\begin{array}{l}-1.289 \\
(2.101)\end{array}$ & $\begin{array}{l}-1.417 \\
(2.053)\end{array}$ \\
\hline Trend Productivity Growth Rate & $\begin{array}{l}0.768^{\star \star \star} \\
(0.101)\end{array}$ & $\begin{array}{l}0.826^{\star \star \star} \\
(0.118)\end{array}$ & $\begin{array}{l}0.891^{\star \star \star} \\
(0.120)\end{array}$ & $\begin{array}{l}0.471^{\star \star \star} \\
(0.154)\end{array}$ & $\begin{array}{c}0.662^{\star \star \star} \\
(0.130)\end{array}$ & $\begin{array}{l}0.721^{\star \star \star} \\
(0.0968)\end{array}$ & $\begin{array}{l}0.779^{\star \star \star} \\
(0.101)\end{array}$ & $\begin{array}{l}-0.0674 \\
(0.662)\end{array}$ & $\begin{array}{c}0.151 \\
(0.466)\end{array}$ \\
\hline $\begin{array}{l}\text { Change in Foreign Value Added } \\
\text { as a Share of Exports }\end{array}$ & & $\begin{array}{c}0.0262 \\
(0.0452)\end{array}$ & & & & & & & \\
\hline Change in Relative Price of Investment ${ }^{2}$ & & & $\begin{array}{l}0.0911^{\star * \star} \\
(0.0338)\end{array}$ & & & & & & \\
\hline Change in Union Density Rate ${ }^{2}$ & & & & $\begin{array}{l}-0.390^{*} \\
(0.234)\end{array}$ & & & & & $\begin{array}{l}-0.483 \\
(0.373)\end{array}$ \\
\hline $\begin{array}{l}\text { Change in Individual and Collective } \\
\text { Dismissal Regulation }\end{array}$ & & & & & $\begin{array}{l}-0.390 \\
(1.653)\end{array}$ & & & & \\
\hline Expected Growth & & & & & & $\begin{array}{l}0.414^{\star \star} \\
(0.197)\end{array}$ & & & \\
\hline $\begin{array}{l}\text { Change in Share of Service Sector } \\
\text { Workers }\end{array}$ & & & & & & & $\begin{array}{l}-0.0424 \\
(0.0308)\end{array}$ & & \\
\hline Union Density Rate (Level) & & & & & & & & $\begin{array}{c}0.542 \\
(0.510)\end{array}$ & $\begin{array}{c}0.302 \\
(0.302)\end{array}$ \\
\hline First-Stage F-statistics above 10 & yes & yes & yes & yes & yes & yes & yes & yes & yes \\
\hline Country Fixed Effects & yes & yes & yes & yes & yes & yes & yes & yes & yes \\
\hline Year Fixed Effects & no & no & no & no & no & no & no & no & no \\
\hline Number of Observations & 361 & 311 & 274 & 241 & 203 & 361 & 361 & 221 & 219 \\
\hline$R^{2}$ & 0.678 & 0.676 & 0.654 & 0.612 & 0.632 & 0.682 & 0.680 & 0.264 & 0.369 \\
\hline
\end{tabular}

Extensions of the baseline approach to include these slower-moving factors show that a proxy for automation (the relative price of investment goods) and diminished medium-term growth expectations appear to weigh on wage growth alongside the influence of the forces discussed above. ${ }^{24}$

While other results are robust to whether the years of the Great Recession are included or not, some coefficients are sensitive to the choice of period. Automation - as proxied by a decline in the relative price of investment goods - and diminished medium-term growth expectations consistently weigh on nominal wage growth, regardless of whether the Great Recession years are included. However, the coefficient on the change in union density is sensitive to both the choice of sample years and the inclusion of its level as an additional control. Changes in regulations related to individual and collective dismissals (a measure of employment protection) do not have a statistically significant effect on nominal wage growth. Because these factors may be interrelated (an increase in global value chain

\footnotetext{
${ }^{24}$ A decline in the relative price of investment goods can lower the cost of automating routine tasks (Autor and Dorn, 2013). However, this proxy may not fully capture the impact of automation on wages - for example, advances in artificial intelligence that allow for automation may not be perfectly measured in the relative price of investment goods.
} 
Table 10. Drivers of Involuntary Part-Time Employment Share, Aggregate Analysis

\begin{tabular}{|c|c|c|c|c|c|c|}
\hline & $(1)$ & $(2)$ & $(3)$ & $(4)$ & $(5)$ & $(6)$ \\
\hline Output Gap & $\begin{array}{c}-0.265^{\star \star \star} \\
(0.030)\end{array}$ & $\begin{array}{c}-0.263^{\star \star \star} \\
(0.029)\end{array}$ & $\begin{array}{c}-0.172^{\star \star *} \\
(0.029)\end{array}$ & $\begin{array}{c}-0.238^{\star * *} \\
(0.031)\end{array}$ & $\begin{array}{c}-0.172^{\star * \star} \\
(0.033)\end{array}$ & $\begin{array}{c}-0.245^{\star \star *} \\
(0.030)\end{array}$ \\
\hline Expected Growth & & $\begin{array}{c}-0.454^{\star * *} \\
(0.134)\end{array}$ & & & & \\
\hline Change in Relative Price of Investment ${ }^{1}$ & & & $\begin{array}{c}-0.122^{\star \star *} \\
(0.018)\end{array}$ & & & \\
\hline Change in Foreign Value Added as a Share of Exports ${ }^{1}$ & & & & $\begin{array}{c}0.037 \\
(0.033)\end{array}$ & & \\
\hline Change in Union Density Rate ${ }^{1}$ & & & & & $\begin{array}{c}0.007 \\
(0.028)\end{array}$ & \\
\hline Change in Share of Service Sector Workers ${ }^{\top}$ & & & & & & $\begin{array}{c}0.085^{\star * *} \\
(0.023)\end{array}$ \\
\hline Country Fixed Effects & yes & yes & yes & yes & yes & yes \\
\hline Year Fixed Effects & yes & yes & yes & yes & yes & yes \\
\hline Number of Observations & 386 & 386 & 357 & 361 & 288 & 386 \\
\hline$R^{2}$ & 0.447 & 0.465 & 0.548 & 0.447 & 0.474 & 0.467 \\
\hline
\end{tabular}

participation and offshoring of production can, for example, contribute to lower unionization), ascribing precise contributions to each factor's influence on recent wage dynamics is inherently difficult. Nevertheless, as seen in Figure 16, the limited decline in the relative price of investment goods in recent years compared to the earlier downward trend suggests that automation (as proxied by this measure) may not have had a large contribution to the subdued wage dynamics following the Great Recession. ${ }^{25}$

Such slower-moving forces may have also played a role in the increase in involuntary parttime employment, beyond the influence of cyclical factors. Table 10 zooms in on the determinants of job attributes and examines the drivers of involuntary part-time employment, linking it to the output gap and the secular drivers explored above. While a more negative output gap (shortfall of actual output relative to the economy's potential) is associated with an increase in the involuntary part-time employment share, other factors, such as mediumterm growth expectations and automation, also appear to have an influence (Figure 18). With declining medium-term growth expectations, firms may have preferred to hire workers parttime. Automation of work processes could have also led to structurally lower demand for labor. A higher services sector share of employment is also associated with an increase in involuntary part-time employment, consistent with the compositional shifts documented in the section on surface healing masking deeper changes in advanced economy labor markets.

\footnotetext{
${ }^{25}$ Studies focusing on long-term effects of automation tend to find larger effects on the wages of particular groups, for example middle-skilled workers (see Autor and Dorn 2013 and Chapter 3 of the April 2017 WEO).
} 
Figure 16. Changes in Growth Expectations and Labor Market Institutions

$$
\text { 2000-07 2012-16 }
$$

4.5- 1. Expected Growth

$4.0^{-}$(Percent, average across advanced economies)

$3.5-$

$3.0^{-}$

$2.5^{-}$

$2.0-$

$1.5-$

$1.0^{-}$

0.5

0.0

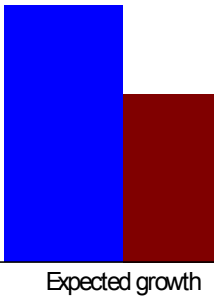

(one year ahead)
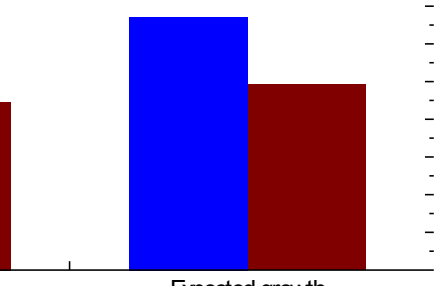

Expected growth

(five years ahead)

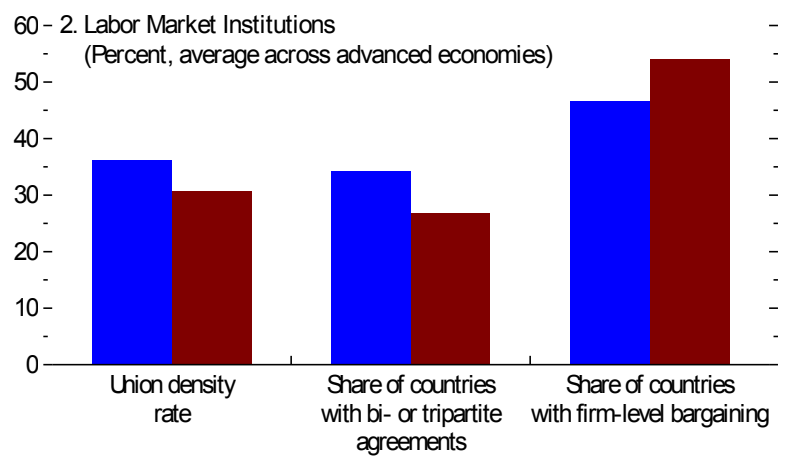

3.0 - 3. Strictness of Employment Protection

(Index, average across advanced economies)

$2.5-$

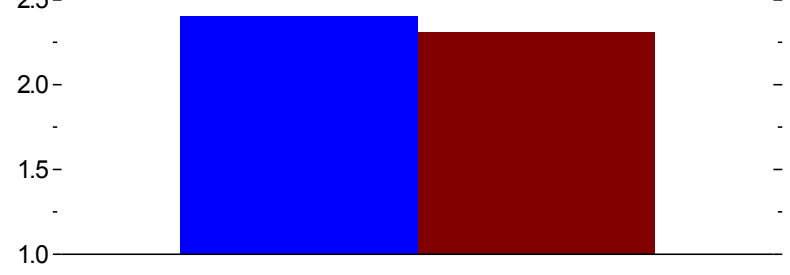

Sources: Institutional Characteristics of Trade Uhions, Wage Setting, State Intervention and Social Pacts database; Organisation for Economic Co-operation and Development; and authors' calculations.

Note: Uhion density rate refers to net union membership as a proportion of wage earners in employment (simple average across countries); bi- or tripartite agreements refers to the existence of a bipartite council of a central union and employers and/or the existence of a tripartite council with government participation. Frm-level bargaining denotes whether bargaining takes place predominantly at the local/company level. Strictness of employment protection refers to individual and collective dismissals (regular contracts). The sample consists of 26-33 advanced economies.
Figure 17. Long-Term Drivers of Labor Market Dynamics

\section{0 - 1. Evolution of Relative Price of Investment in Advanced} Economies (Index)

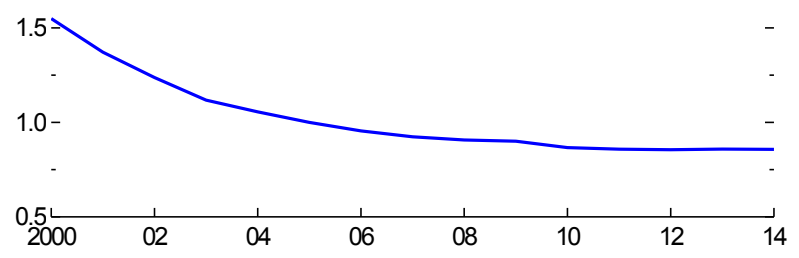

0.4 - 2. Change in Relative Price of Investment by Sector, 2011-13

$0.2-\quad$ (Index, relative to 2000)

0.0

$-0.2-$

$-0.4-$

$-0.6$

$-0.8-$

$-1.0-$

MNG MNF CON INF WHO FN OTH UTL PUB RBS AGR ACC

27 - 3. Evolution of Uhion Density Rates in Advanced Economies (Percent)

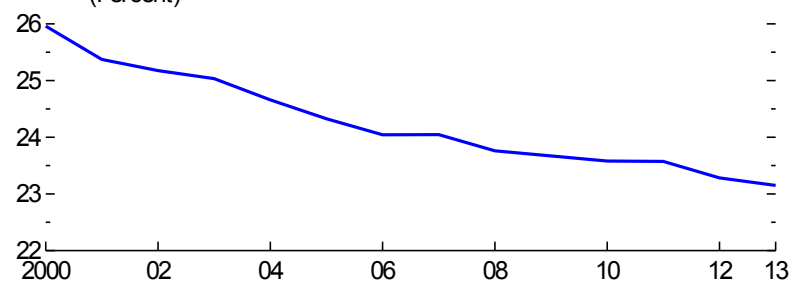

50 - 4. Uhion Density Rates by Sector

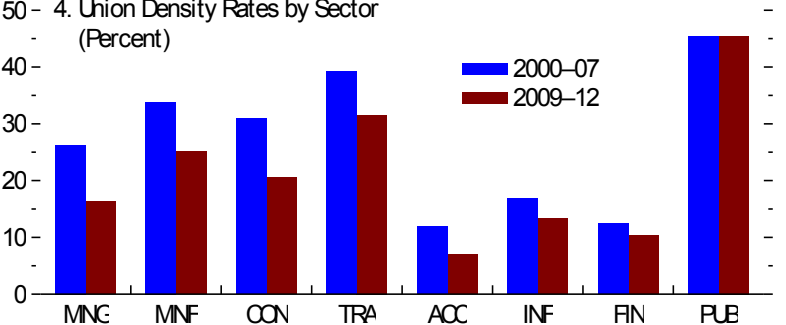

Sources: Institutional Characteristics of Trade Uhions, Wage Setting, State Intervention and Social Pacts database; Penn World Tables Capital Detail; World Bank, World Development Indicators database; and authors' calculations. Note: Numbers for advanced economies are calculated by first aggregating over sectors to the country level using sectoral value added as weight, and subsequently aggregating over countries using nominal GDP as weight. Sectoral numbers are calculated by aggregating over countries using sectoral value added as weight. Sector abbreviations are as defined in Figure 8. 


\section{F. Sectoral Analysis}

As a complement to the aggregate analysis, drivers of nominal wage growth and part-time employment shares are examined at the sectoral level. ${ }^{26}$ Following the structure of the aggregate analysis, sector-level regressions explore the roles of slack, medium-term growth expectations, technological progress, increased trade integration, and changes in labor market institutions. ${ }^{27}$ These are examined as possible drivers of nominal wage growth and part-time employment to determine their effect on different margins of adjustment. The analysis exploits variation in sectoral exposure to aggregate forces to shed light on mechanisms that

Figure 18. Effects on Involuntary Part-Time Employment Share, Aggregate Analysis (Percentage points)

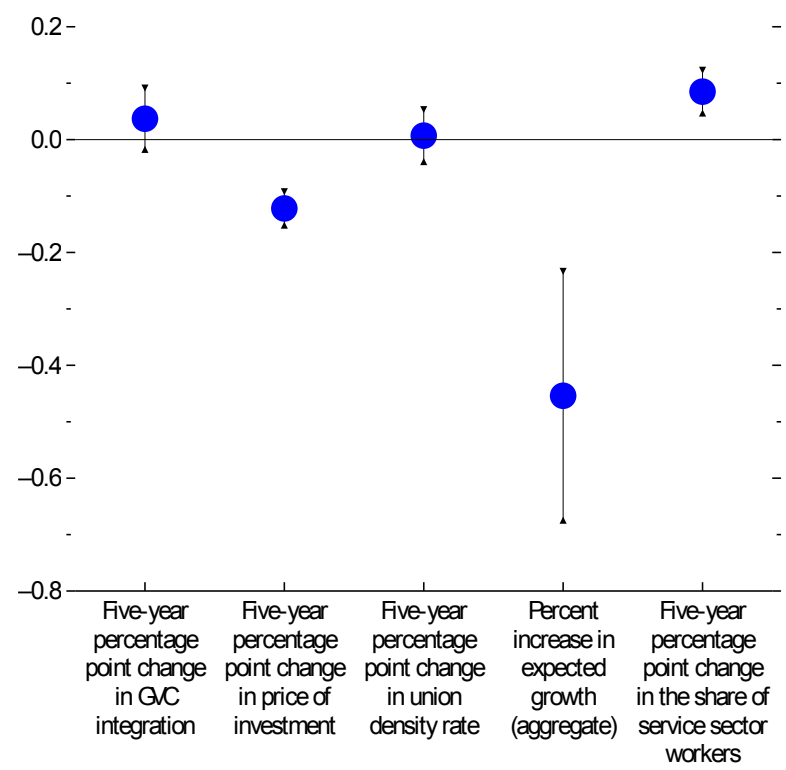

Source: Authors' calculations.

Note: Markers show estimated coefficients, and lines display 90 percent confidence intervals. Figure is based on columns (2) to (6) of Table 10. GMC= global value chain. operate within countries. ${ }^{28}$

As noted earlier, across several advanced economies, a rise in involuntary part-time employment has accompanied subdued wage growth, even as headline employment has fallen. These developments have occurred in the context of falling growth expectations and declines in worker bargaining power, as shown in Figures 15 and 2.16. ${ }^{29}$

The sectoral analysis examines the effects of increasing trade openness, automation (captured by the declining relative price of investment), and slowing sectoral growth rates (used to construct a measure of adaptive growth expectations at the sectoral level) on nominal wage growth and parttime employment as a share of total

\footnotetext{
${ }^{26}$ Estimates of involuntary part-time employment are not available at the sectoral level, so the focus here is on total part-time employment, including both voluntary and involuntary.

${ }^{27}$ Control variables are in line with those used in ECB (2009) and EC (2003), as well as in the literature on interindustry wage differentials and wage dispersion (for example, Erdil and Yetkiner 2001; Koeniger, Leonardi, and Nunziata 2007; and Du Caju and others 2010). Wage regressions also control for inflation and (sectoral) trend productivity growth.

${ }^{28}$ The regressions also control for country, sector, and year fixed effects.

${ }^{29}$ Panel 4 of Figure 1 shows the decline in union density rates occurring in most sectors, with the notable exception of public administration; coverage of sectoral union density rates is unfortunately too limited to be included in the regression analysis.
} 
employment. ${ }^{30}$ It does so by exploiting sectoral variations in exposure to aggregate forces (Table 11). For instance, country-level slack could be expected to matter more for labor market dynamics in sectors that are more correlated with the aggregate economy, and the effects of a decline in the aggregate relative price of investment could vary by the initial capital intensity of the sector.

\begin{tabular}{|c|c|c|c|}
\hline & Measure & Aggregate Variable & Sectoral Variation \\
\hline Near-Term Factors & $\begin{array}{c}\text { Slack } \\
\text { Inflation }\end{array}$ & $\begin{array}{l}\text { Aggregate output gap, } \\
\text { inflation }\end{array}$ & Interaction with sectoral correlation \\
\hline Medium-Term Factors & Trend Productivity Growth & & Five-year trailing average of productivity growth \\
\hline \multirow{3}{*}{ Long-Term Factors } & Expected Growth & $\begin{array}{c}\text { Expected growth } \\
\text { (one and five years ahead) }\end{array}$ & $\begin{array}{l}\text { Interaction with sectoral correlation; } \\
\text { sectoral expected growth (adaptive) }\end{array}$ \\
\hline & Technological Progress & $\begin{array}{l}\text { Change in relative price of } \\
\text { investment }\end{array}$ & $\begin{array}{l}\text { Interaction with sectoral capital intensity; } \\
\text { change in sectoral price of investment }\end{array}$ \\
\hline & Worker Bargaining Power & $\begin{array}{l}\text { Union density rate, } \\
\text { bi- or tripartite agreement, } \\
\text { level of bargaining }\end{array}$ & $\begin{array}{c}\text { Interactions with sectoral characteristics: } \\
\text { high expected growth } \\
\text { high volatility }\end{array}$ \\
\hline
\end{tabular}

Note: Sample comprises 20 advanced economies: Australia, Austria, Belgium, Canada, Czech Republic, Denmark, Finland, France, Germany, Ireland, Italy, Netherlands, Norway, Portugal, Spain, Slovak Republic, Slovenia, Sweden, United Kingdom, United States.

The analysis relies on annual data for a sample of 20 advanced economies starting in 2000, and relates changes in nominal wage growth to the same cyclical and secular drivers used in the aggregate analysis, controlling for country, sector, and year fixed effects:

$$
y_{i j t}=\alpha_{i}+\mu_{j}+\tau_{t}+\boldsymbol{\beta} \boldsymbol{X}_{i j t}+\boldsymbol{\gamma} \boldsymbol{Z}_{j t}
$$

in which $y_{i j t}$ is nominal wage growth, $\boldsymbol{X}_{i j t}$ includes measures that vary at the country-sector level, such as the share of part-time employment, how correlated a sector's gross output growth is with the overall economy, sectoral trend productivity growth (measured again using a five-year trailing average), sectoral expected growth (an adaptive measure based on a five-year trailing average of sectoral gross output growth), and the five-year change in final imports as a share of gross output.

$Z_{j t}$ includes measures that vary only at the country level, such as the aggregate output gap and (lagged) inflation, the change in the relative price of investment, and measures of worker bargaining power (proxied again using the five-year change in the union density rate). To exploit sectoral variation in exposure to aggregate forces, these are interacted with sectoral characteristics, looking at the interaction of the aggregate output gap with the correlation of

\footnotetext{
${ }^{30}$ Sectoral expected growth is measured as the five-year trailing average of sectoral gross output growth rates. As noted above, this could be capturing expected productivity growth as well as demand conditions.
} 
the sector and the aggregate economy and the interaction of the change in the relative price of investment with sectoral capital intensity.

As in the aggregate regressions, the sectoral analysis relates the share of part-time employment to slack (captured using the output gap and how correlated a sector is with the aggregate economy and the interaction between these two variables) and to secular drivers: expected growth, change in final imports as a share of gross output, change in the relative price of investment (also interacted with capital intensity), and change in the union density rate.

Sectoral data have many more missing observations than country-level data, resulting in an unbalanced panel, and sectoral measurements are likely noisier. Although the results of the sectoral regressions are not as conclusive as those based on the country panel regressions presented earlier, they tend to be consistent.

Tables 12 and 13 report the results of the sectoral analysis, linking growth in nominal wages and part-time employment to cyclical and secular drivers. These include country, sector, and year fixed effects - results are robust to including interacted sector-year fixed effects instead, which would pick up common sectoral developments across countries. Diminished sector-specific slack is associated with higher nominal wage growth in countries where unemployment in 2016 was below
Figure 19. Decomposition of Sectoral Wage Dynamics, 2000-15

(Percentage point change relative to 2000-07 average)

$$
\begin{array}{lll}
\text { Actual } & \text { Slack } & \text { Year fixed effects }
\end{array}
$$

4 - 1. Unemployment Rates Lower than 2000-07 Average

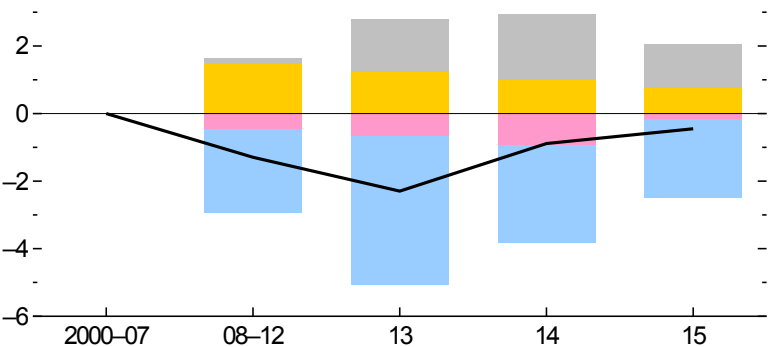

2- 2. Unemployment Rates Moderately Higher than 2000-07 Average

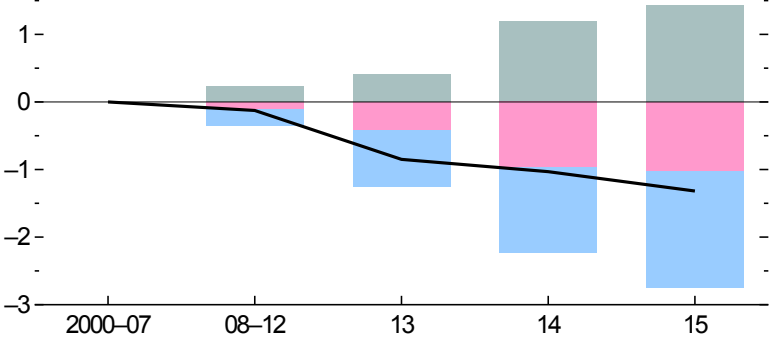

5.0 - 3. Unemployment Rates Appreciably Hgher than 2000-07 Average

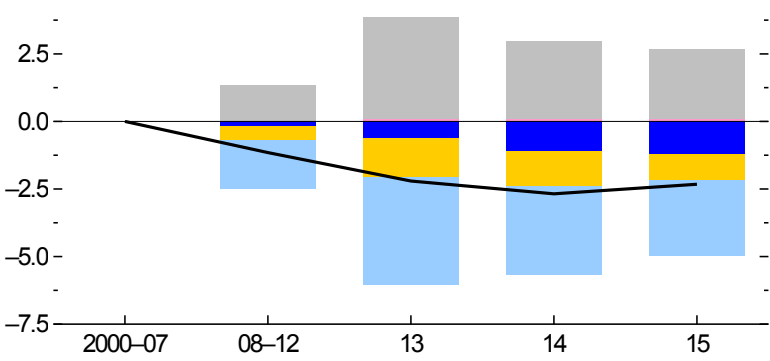

Source: Authors' calculations

Note: Groups are as defined in Table 5. Structural factors include automation (proxied by the relative price of investment), trade, and expected growth. Regressions also control for trend labor productivity growth, the share of part-time employment, as well as country and sector fixed effects. The decomposition is based on the coefficients reported in Table 12 and is weighted by GDP at market exchange rates across countries. Only statistically significant coefficients are shown.

2000-07 averages (as captured by the sum of the impacts of the aggregate output gap, the correlation between the sector and the aggregate economy, and their interaction-Figure 19, panel 1). Automation and medium-term growth expectations have been generally associated with lower wage growth in these economies. Where unemployment rates are still appreciably above 2000-07 averages, slack and past inflation are the largest drags on nominal wage growth (Figure 19, panel 3). For countries with unemployment rates only moderately above their former averages, structural factors - automation and medium-term growth expectations - play a role (Figure 19, panel 2). Although sectoral productivity growth does 
not have a significant effect in the sectoral analysis, this finding could result from spillovers of wage pressures across sectors and cross-sector labor mobility. These spillovers tend to weaken links between sector-level drivers and sectoral nominal wage growth.

Automation and lower sectoral medium-term growth expectations are also associated with higher shares of part-time employment across sectors, and the associations are broadly similar in size to those found in the aggregate analysis for involuntary part-time employment (Figure 20; Table 13).

Table 14 reports the robustness test in which growth in nominal wages, employment, and part-time employment are treated as jointly determined and estimates the system using three-stage least squares, which treats the dependent variables as endogenous, instruments them using the exogenous variables, and allows them to be correlated with disturbances in the system's equations.

The results are also robust to looking at three-year nonoverlapping averages of the dependent and explanatory variables instead of annual data. Furthermore, as in the aggregate analysis, results are robust to omitting smaller advanced economies (the Baltic countries). While skill composition is not included in the baseline specifications due to data limitations, the results are robust to including it as an additional control.

Further robustness tests have explored alternative trade measures, such as exports and intermediate exports as a share of gross output and global value chain participation, aggregate expected growth (one and five years ahead) interacted with sectoral correlation instead of sectoral expected growth, and further measures of worker bargaining power. Such further measures include whether the country has a bi- or tripartite agreement, whether bargaining is done predominantly by firms (as opposed to at the sector or country level), the ease of hiring and firing, and the strictness of employment protection regulation. Results on other variables are broadly comparable to those in the baseline regressions. 
Table 12. Drivers of Sectoral Nominal Wage Growth

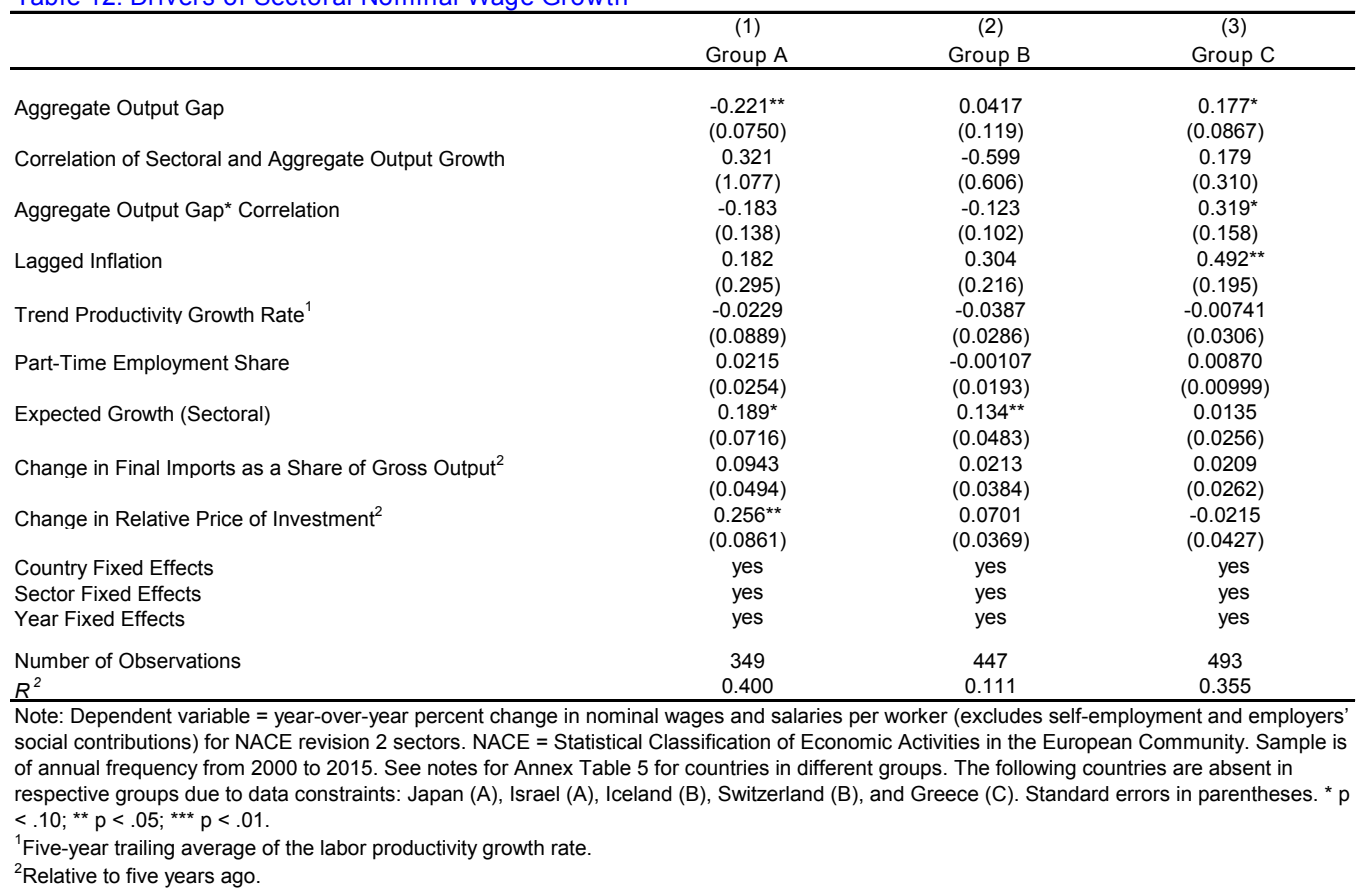

Table 13. Drivers of Sectoral Part-Time Employment Shares

\begin{tabular}{|c|c|c|c|c|c|c|}
\hline & (1) & $(2)$ & (3) & $(4)$ & $(5)$ & (6) \\
\hline Aggregate Output Gap & $\begin{array}{c}-0.0273 \\
(0.0710)\end{array}$ & $\begin{array}{r}-0.00807 \\
(0.0685)\end{array}$ & $\begin{array}{c}0.0237 \\
(0.0736)\end{array}$ & $\begin{array}{l}0.00105 \\
(0.0781)\end{array}$ & $\begin{array}{c}0.0124 \\
(0.0595)\end{array}$ & $\begin{array}{r}-0.00168 \\
(0.0830)\end{array}$ \\
\hline Correlation of Sectoral and Aggregate Output Growth & $\begin{array}{l}-0.318 \\
(0.512)\end{array}$ & $\begin{array}{l}-0.355 \\
(0.514)\end{array}$ & $\begin{array}{l}-0.321 \\
(0.454)\end{array}$ & $\begin{array}{l}-0.290 \\
(0.478)\end{array}$ & $\begin{array}{c}0.254 \\
(0.479)\end{array}$ & $\begin{array}{l}-0.441 \\
(0.773)\end{array}$ \\
\hline Aggregate Output Gap * Correlation & $\begin{array}{l}-0.0703 \\
(0.0739)\end{array}$ & $\begin{array}{l}-0.0779 \\
(0.0727)\end{array}$ & $\begin{array}{c}-0.115 \\
(0.0788)\end{array}$ & $\begin{array}{l}-0.0297 \\
(0.0686)\end{array}$ & $\begin{array}{l}-0.0204 \\
(0.0924)\end{array}$ & $\begin{array}{c}0.0285 \\
(0.0831)\end{array}$ \\
\hline Expected Growth (Aggregate) & & $\begin{array}{l}-0.615^{*} \\
(0.322)\end{array}$ & & & & \\
\hline Expected Growth (Sectoral) & & & $\begin{array}{l}-0.137^{\star *} \\
(0.0573)\end{array}$ & & & \\
\hline Change in Final Imports as a Share of Gross Output ${ }^{1}$ & & & & $\begin{array}{c}-0.0577 \\
(0.0367)\end{array}$ & & \\
\hline Change in Relative Price of Investment ${ }^{1}$ & & & & & $\begin{array}{c}-0.147^{\star * *} \\
(0.0464)\end{array}$ & \\
\hline Change in Relative Price of Investment* Capital Intensity & & & & & $\begin{array}{c}0.00118^{* *} \\
(0.000419)\end{array}$ & \\
\hline Capital Intensity & & & & & $\begin{array}{c}5.052 \\
(4.032)\end{array}$ & \\
\hline Change in Union Density Rate ${ }^{1}$ & & & & & & $\begin{array}{c}0.106 \\
(0.0749)\end{array}$ \\
\hline Country Fixed Effects & yes & yes & yes & yes & yes & yes \\
\hline Sector Fixed Effects & yes & yes & yes & yes & yes & yes \\
\hline Year Fixed Effects & yes & yes & yes & yes & yes & yes \\
\hline Number of Observations & 2103 & 2103 & 2103 & 1687 & 1710 & 1562 \\
\hline$R^{2}$ & 0.806 & 0.806 & 0.807 & 0.811 & 0.810 & 0.824 \\
\hline
\end{tabular}




\begin{tabular}{|c|c|c|c|c|c|}
\hline & (1) & $(2)$ & (3) & $(4)$ & \multirow{3}{*}{$\begin{array}{c}(5) \\
\text { Part-Time } \\
\text { Employment }^{1} \\
3 S L^{3} S^{3}\end{array}$} \\
\hline & \multicolumn{2}{|c|}{ Nominal Wage Growth ${ }^{1}$} & \multicolumn{2}{|c|}{$\begin{array}{l}\text { Employment } \\
\text { Growth }^{1}\end{array}$} & \\
\hline & $3 S L^{2}$ & $3 S L^{3}$ & $3 S S^{2}$ & $3 S L S^{3}$ & \\
\hline \multirow[t]{2}{*}{ Aggregate Output gap } & $0.284^{* \star *}$ & $0.241^{* * *}$ & -0.0682 & -0.0513 & -0.0907 \\
\hline & $(0.0334)$ & $(0.0322)$ & $(0.0786)$ & $(0.0641)$ & $(0.0816)$ \\
\hline \multirow[t]{2}{*}{ Correlation of Sectoral and Aggregate Output Growth } & $-0.388^{\star \star}$ & $-0.412^{\star \star}$ & $-1.001^{\star *}$ & -0.226 & $-0.698^{*}$ \\
\hline & $(0.172)$ & $(0.163)$ & $(0.404)$ & $(0.324)$ & $(0.413)$ \\
\hline \multirow[t]{2}{*}{ Aggregate Output Gap* Correlation } & $0.321^{* * *}$ & $0.269^{* * *}$ & $0.606^{* \star *}$ & $0.644^{\star \star \star}$ & 0.000166 \\
\hline & $(0.0548)$ & $(0.0531)$ & $(0.129)$ & $(0.106)$ & $(0.135)$ \\
\hline \multirow[t]{2}{*}{ Lagged Inflation } & $0.207^{\star \star \star}$ & $0.210^{\star \star *}$ & 0.0552 & -0.0967 & 0.131 \\
\hline & $(0.0573)$ & $(0.0578)$ & $(0.135)$ & $(0.115)$ & $(0.147)$ \\
\hline \multirow[t]{2}{*}{ Expected Growth (Sectoral) } & 0.0205 & $0.0226^{*}$ & $-0.0700^{\star *}$ & -0.0337 & $-0.106^{\star \star \star}$ \\
\hline & $(0.0138)$ & $(0.0137)$ & $(0.0324)$ & $(0.0272)$ & $(0.0347)$ \\
\hline \multirow[t]{2}{*}{ Change in Final Imports as a Share of Gross Output ${ }^{4}$} & -0.0103 & -0.00520 & 0.0280 & 0.0218 & $0.0588^{\star \star}$ \\
\hline & $(0.0110)$ & $(0.00973)$ & $(0.0258)$ & $(0.0194)$ & $(0.0247)$ \\
\hline \multirow[t]{2}{*}{ Change in the Relative Price of Investment ${ }^{4}$} & $0.102^{* \star *}$ & $0.115^{\star \star \star}$ & 0.0294 & 0.0133 & -0.0683 \\
\hline & $(0.0228)$ & $(0.0213)$ & $(0.0537)$ & $(0.0424)$ & $(0.0540)$ \\
\hline Country Fixed Effects & yes & yes & yes & yes & yes \\
\hline Sector Fixed Effects & yes & yes & yes & yes & yes \\
\hline Year Fixed Effects & no & no & no & no & no \\
\hline Number of Observations & 1833 & 1526 & & & \\
\hline \multicolumn{6}{|c|}{$\begin{array}{l}\text { Note: Sample is of annual frequency from } 2000 \text { to } 2015 \text {. See Table } 1 \text { for countries in the sample. } 3 \text { SLS }=\text { three stage least squares. } \\
\text { Standard errors in parentheses. }{ }^{*} p<.10 ;{ }^{* *} p<.05 ;{ }^{* \star *} p<.01 \text {. }\end{array}$} \\
\hline \multicolumn{6}{|c|}{${ }^{1}$ The dependent variable of the regression, defined as annual growth rates and share of total employment. } \\
\hline \multicolumn{6}{|c|}{${ }^{2}$ System estimated using $3 S L S$ for nominal wage growth and employment growth as the endogenous dependent variables. } \\
\hline \multicolumn{6}{|c|}{$\begin{array}{l}{ }^{3} \text { System estimated using } 3 S L S \text { for nominal wage growth, employment growth, and the share of part-time employment as the endogenous } \\
\text { dependent variables. }\end{array}$} \\
\hline
\end{tabular}

\section{SUMMARY AND POLICY IMPLICATIONS}

The analysis in this paper finds that while labor market slack is a key driver behind sluggish wage dynamics, headline unemployment rates may not be as indicative of labor market slack as they used to be. Following the global financial crisis, several advanced economies have experienced higher rates of involuntary part-time employment and an increased share of temporary employment contracts. Hours per worker have also continued to decline (extending a trend that began before the Great Recession).

Aggregate developments in part-time employment, temporary contracts, and hours in part reflect continued weak demand for labor (itself a reflection of weak final demand for goods and services). They also reflect compositional shifts in employment away from sectors that tend to have traditional employment arrangements (smaller shares of part-time employment, a smaller proportion of temporary contracts, longer hours per worker) toward sectors where more flexible arrangements dominate. However, there is less evidence that sectoral shifts in employment account for subdued wage growth.

The analysis finds that at the country level, labor market slack, together with weak productivity growth and low inflation expectations, are the main forces weighing on wage growth. Automation (proxied in the analysis by the relative price of investment goods) appears to have made a small contribution to subdued wage dynamics following the Great Recession due to a limited decline in the relative price of investment goods in recent years compared to the previous downward trend. The analysis suggests that automation could 
weigh on wage growth more substantially in the future if the decline in the relative price of investment goods were to pick up again. However, inferences about the impact of automation are not straightforward given that, as noted previously, the relative price of investment goods is just one channel through which its influence on wage growth may play out.

The relative roles of labor market slack and productivity growth vary across countries. In economies where unemployment rates are still appreciably above their averages before the Great Recession (such as Italy, Portugal, and Spain), high unemployment can explain about half of the slowdown in nominal wage growth since 2007, with involuntary part-time employment acting as a further drag on wages. Wage growth is therefore unlikely to pick up until slack diminishes meaningfully — an outcome that requires continued accommodative policies to boost aggregate demand.

In economies where unemployment rates are below their averages before the Great Recession (such as Germany, Japan, the United States, and the United Kingdom), slow productivity growth can account for about two-thirds of the slowdown in nominal wage growth since 2007. Even here, however, involuntary part-time employment appears to be weighing on wage growth, suggesting greater slack in the labor market than headline unemployment rates capture. Assessing the true degree of slack in these economies will be important when determining the appropriate pace of exit from accommodative monetary policies.

The evidence also suggests that involuntary part-time employment is in turn associated with both cyclical factors and slower-moving drivers, such as automation, diminished mediumterm growth expectations, and the growing importance of the services sector. Some of these developments point to a persistent shift in the nature of work and employment relations. Policymakers may therefore need to enhance efforts to address the vulnerabilities that parttime workers face. Examples of possible initiatives include strengthening secondary and tertiary education to upgrade skills over the longer term; broadening minimum wage coverage where it does not currently include part-time workers; offering prorated paid annual, family, and sick leave to secure parity with full-time workers; and providing subsidized training for part-time workers for reskilling and retooling (see also the October 2017 Fiscal Monitor and Golden 2016 for a summary of measures taken by various cities in the United States, for example). However, any policy actions to address the income security of workers that hold part-time jobs or temporary contracts, should be designed to minimize possible adverse impacts on the flexibility of labor markets and job creation.

More generally, the rise of part-time employment and temporary contracts challenges the current structure of social insurance systems - instituted in many advanced economies in the aftermath of the Great Depression and World War II-which may be better equipped to handle "binary" employment status (people in the labor force are either employed full-time or unemployed). To the extent that changes in the nature of employment are not purely cyclical, but also related to longer-term shifts in structural factors, a broader rethink of the nature of social insurance may be needed. 


\section{REFERENCES}

Aaronson, Daniel, and Andrew Jordan. 2014. "Understanding the Relationship between Real Wage Growth and Labor Market Conditions.” Chicago Fed Letter 327. Federal Reserve Bank of Chicago.

Adler, Gustavo, Romain Duval, Davide Furceri, Sinem Kiliç Çelik, Ksenia Koloskova, and Marcos Poplawski-Ribeiro. 2017. "Gone with the Headwinds: Global Productivity.” IMF Staff Discussion Note 17/04, International Monetary Fund, Washington, DC.

Almeida, Heitor, Murillo Campello, Bruno Laranjeira, and Scott Weisbenner. 2012. "Corporate Debt Maturity and the Real Effects of the 2007 Credit Crisis." Critical Finance Review 1 (1): 3-58.

Altig, David E., and P. Higgins. 2014. “The Wrong Question?” Federal Reserve Bank of Atlanta, Macroblog, June 20.

Aoyagi, Chie, and Giovanni Ganelli. 2015. “Does Revamping Japan's Dual Labor Market Matter?” Economic Systems 39 (2): 339-57.

Autor, David H. 2017. "How Long Has This Been Going On? A discussion of "Recent Flattening in the Higher Education Wage Premium: Polarization, Skill Downgrading, or Both?” by Robert G. Valletta. National Bureau of Economic Research, Conference on Research and Income in Wealth.

—, and David Dorn. 2013. "The Growth of Low-Skill Services Jobs and the Polarization of the US Labor Market." American Economic Review 103 (5): 1553-97.

— Lawrence F. Katz, and Melissa S. Kearney. 2008. "Trends in US Wage Inequality: Revising the Revisionists." Review of Economics and Statistics 90 (2): 300 23.

— Lawrence F. Katz, and Alan B. Krueger. 1998. "Computing Inequality: Have Computers Changed the Labor Market?" Quarterly Journal of Economics 113: 1169-215.

Ball, Laurence, and Robert Moffitt. 2001. "Productivity Growth and the Phillips Curve." Economics Working Paper Archive 450, Johns Hopkins University Department of Economics, Baltimore, MD.

Bank of England. 2017. "Why Has Wage Growth Remained Subdued?” Box in Chapter 3, Inflation Report, February. 
Beaudry, Paul, David A. Green, and Benjamin M. Sand. 2014. "The Declining Fortunes of the Young since 2000." American Economic Review 104 (5): 381-86.

- 2016. "The Great Reversal in the Demand for Skill and Cognitive Tasks." Journal of Labor Economics 34 (S1, Part 2): S199-247.

Bentolila, Samuel, Pierre Cahuc, Juan J. Dolado, and Thomas Le Barbanchon. 2012. "TwoTier Labor Markets in the Great Recession: France versus Spain." The Economic Journal, 122, F155-F187.

Berman Eli, John Bound, and Zvi Griliches. 1994. "Changes in the Demand for Skilled Labor within US Manufacturing: Evidence from the Annual Survey of Manufacturers." Quarterly Journal of Economics 109 (2): 367-97.

Blanchard, Olivier, and Francesco Giavazzi. 2003. "Macroeconomic Effects of Regulation and Deregulation in Goods and Labor Markets." Quarterly Journal of Economics 118 (3): 879-907.

Blanchard, Olivier, and Lawrence F. Katz, 1997. "Wage Dynamics: Reconciling Theory and Evidence." American Economic Review 89 (2): 69-74.

Blanchflower, David G., and Adam S. Posen. 2014. "Wages and Labor Market Slack: Making the Dual Mandate Operational.” PIIE Policy Brief 14-10.

Borjas, George J., and Valerie A. Ramey. 1995. "Foreign Competition, Market Power, and Wage Inequality.” Quarterly Journal of Economics 110 (4): 1075-110.

Borowczyk-Martins, Daniel, Gregory Jolivet, and Fabien Postel-Vinay. 2013. "Accounting for Endogeneity in Matching Function Estimation." Review of Economic Dynamics 16 (3): 440-51.

Brainard, Lael. 2016. "The 'Gig' Economy: Implications of the Growth of Contingent Work." Speech at the "Evolution of Work" conference, November 17. https://www.federalreserve.gov/newsevents/speech/brainard20161117a.htm.

Burda, Michael C., and Stefanie Seele. 2016. "No Role for the Hartz Reforms? Demand and Supply Factors in the German Labor Market, 1993-2014.” SFB 649 Discussion Paper 2016-010, Humboldt University, Berlin.

Burtless Gary. 1995. "International Trade and the Rise in Earnings Inequality." Journal of Economic Literature 33 (2): 800-16.

Byrne, David M., John G. Fernald, and Marshall B. Reinsdorf. 2016. "Does the United States Have a Productivity Slowdown or a Measurement Problem?” Working Paper Series 2016-3, Federal Reserve Bank of San Francisco. 
Cho, Sang-Wook (Stanley), and Julían P. Díaz. 2016. "Skill Premium Divergence: The Roles of Trade, Capital, and Demographics." The Future of Europe: Central and Eastern Europe in a Comparative Perspective conference.

Council of Economic Advisers. 2014. Economic Report of the President. Washington, DC.

Daly, Mary, and Bart Hobijn. 2015. “Why Is Wage Growth So Slow?” Federal Reserve Bank of San Francisco Economic Letter 2015-01, January.

Danninger, Stephan. 2016. "What's Up with US Wage Growth and Job Mobility?" IMF Working Paper 16/122, International Monetary Fund, Washington DC.

Das, Mitali. and Benjamin. Hilgenstock. Forthcoming. "Labor Market Consequences of Routinization in Developed and Developing Economies." Unpublished.

Davis, Steven J., and John Haltiwanger. 2014. "Labor Market Fluidity and Economic Performance.” NBER Working Paper 20479, National Bureau of Economic Research, Cambridge, MA.

Dew-Becker, Ian, and Robert J. Gordon. 2005. "Where Did Productivity Growth Go? Inflation Dynamics and the Distribution of Income." Brookings Papers on Economic Activity 36 (2): 67-150.

DiNardo, John, and David Card. 2002. "Skill Biased Technological Change and Rising Wage Inequality: Some Problems and Puzzles.” Journal of Labor Economics 20 (4): 733-83.

Du Caju, Philip, Gábor Kátay, Ana Lamo, Daphne Nicolitsas, and Steven Poelhekke. 2010. "Inter-Industry Wage Differentials in EU Countries: What Do Cross-Country Time-Varying Data Add to the Picture?” European Central Bank Working Paper 189, Frankfurt.

Duval, Romain, Gee Hee Hong, and Yannick Timmer. 2017. "Financial Frictions and the Great Productivity Slowdown.” IMF Working Paper 17/129, International Monetary Fund, Washington DC.

Erdil, Erkan, and I. Hakan Yetkiner. 2001. "A Comparative Analysis of Inter-Industry Wage Differentials: Industrialized versus Developing Countries." Applied Economics 33 (13): 1639-48.

European Central Bank (ECB). 2009. "Wage Dynamics in Europe: Final Report of the Wage Dynamics Network." Directorate General Research, Frankfurt. 2017. “Assessing Labor Market Slack.” Economic Bulletin 3. 
European Commission (EC). 2003. "Wage Structures and Determinants in an Enlarged Europe." In Employment in Europe 2003: Recent Trends and Prospects. Directorate-General for Employment and Social Affairs, Frankfurt.

European Union (EU). 2015. "Wage and Income Inequality in the European Union." Directorate-General for Internal Policies, Policy Department Economic and Scientific Policy, Frankfurt.

Feenstra, Robert, and Gordon Hanson. 1996. "Foreign Investment, Outsourcing and Relative Wages." In The Political Economy of Trade Policy: Paper in Honour of Jagdish Bhagwati, edited by Robert Feenstra, Gene Grossman, and Douglas Irwin, 89-127. Cambridge, MA: MIT Press.

— 2001. "Global Production Sharing and Rising Inequality: A Survey of Trade and Wages." NBER Working Paper 8372, National Bureau of Economic Research, Cambridge, MA.

Fernald, John G. 2014. "Productivity and Potential Output before, during, and after the Great Recession." NBER Working Paper 20248, National Bureau of Economic Research, Cambridge, MA.

Gal, Peter, and Alexander Hijzen. 2016. "The Short-Term Impact of Product Market Reforms: A Cross-Country Firm-Level Analysis.” IMF Working Paper 16/116, International Monetary Fund, Washington DC.

Gali, Jordi. 2011. "The Return of the Wage Phillips Curve." Journal of the European Economic Association 9 (3): 436-61.

Golden, Lonnie. 2016. "Still Falling Short on Hours and Pay." Economic Policy Institute, Washington, DC. http://www.epi.org/publication/still-falling-short-on-hoursand-pay-part-time-work-becoming-new-normal/.

Goos, Maarten, Alan Manning, and Anna Salomons. 2014. "Explaining Job Polarization: Routine-Biased Technological Change and Offshoring." American Economic Review 104 (8): 2509-26.

Gordon, Robert. 2013. "The Phillips Curve Is Alive and Well: Inflation and the NAIRU during the Slow Recovery." NBER Working Paper 19390, National Bureau of Economic Research, Cambridge, MA.

Haldane, Andrew G. 2017. "Work, Wages, and Monetary Policy." Speech given at the National Science and Media Museum, Bradford, United Kingdom, June 20. http://www.bankofengland.co.uk/publications/Pages/speeches/2017/984.aspx. 
Hall, Robert E. 2005. "Employment Fluctuations with Equilibrium Wage Stickiness." American Economic Review 95 (1): 50-65.

International Monetary Fund (IMF). 2016. Japan Article IV Consultation Report. IMF Staff Country Report 16/267, Washington, DC.

Kang, Joong Shik, and Jay C. Shambaugh. 2014. "Progress Towards External Adjustment in the Euro Area Periphery and the Baltics." IMF Working Paper 14/131, International Monetary Fund, Washington, DC.

Karabarbounis, Loukas, and Brent Neiman. 2014. "The Global Decline of the Labor Share." Quarterly Journal of Economics 129 (1): 61-103.

Katz, Lawrence, and David Autor. 1999. "Changes in the Wage Structure and Earnings Inequality." In Handbook of Labor Economics vol. III, edited by Orley Ashenfelter and David Card. Amsterdam: Elsevier.

and Alan Krueger. 2016. "The Rise and Nature of Alternative Work Arrangements in the United States, 1995-2015.” NBER Working Paper 22667, National Bureau of Economic Research, Cambridge, MA.

—_, and Kevin Murphy. 1992. "Changes in Relative Wages, 1963-87: Supply and Demand Factors." Quarterly Journal of Economics 107 (1): 35-78.

Kiley, Michael. 2014. "An Evaluation of the Inflationary Pressure Associated with Shortand Long-term Unemployment." FEDS Notes 2014-28, Federal Reserve Board, Washington, DC.

Koeniger, Winfried, Marco Leonardi, and Luca Nunziata. 2007. "Labor Market Institutions and Wage Inequality." Industrial and Labor Relations Review 60 (3): 340-56.

Kramarz, Francis. 2017. "Offshoring, Wages, and Employment: Evidence from Data Matching Imports, Firms, and Workers." In The Factory Free Economy, edited by Lionel Fontagne and Ann Harrison. https://www.researchgate.net/publication/303374155 The Factory_Free_Eco nomy.

Krueger, Alan. 2015. "How Tight Is the Labor Market?” Martin Feldstein Lecture, National Bureau of Economic Research.

— - Judd Cramer, and David Cho. 2014. "Are the Long-Term Unemployed on the Margins of the Labor Market?" Brookings Papers on Economic Activity, Brookings Institution, Washington, DC. 
Kumar, Anil, and Pia Orrenius. 2016. "A Closer Look at the Phillips Curve Using StateLevel Data.” Journal of Macroeconomics 47: 84-102.

Leamer, Edward. 1992. "Wage Effects of a US-Mexican Free Trade Agreement.” NBER Working Paper 3991, National Bureau of Economic Research, Washington, DC.

- 1996. "Wage Inequality from International Competition and Technological Change: Theory and Country Experience." American Economic Review Papers and Proceedings 86 (2): 309-14.

Manning, Alan. 1993. "Wage Bargaining and the Phillips Curve: The Identification and Specification of Aggregate Wage Equations.” CEP Discussion Paper dp0062, Centre for Economic Performance, London School of Economic, London.

Mortensen, Dale T., and Christopher A. Pissarides. 1999. "Job Reallocation, Employment Fluctuations and Unemployment.” Handbook of Macroeconomics 1, 1171228. Amsterdam: Elsevier.

Organisation for Economic Co-operation and Development (OECD). 2017. "Economic Policy Reforms 2017: Going for Growth.” Paris.

Parteka, Aleksandra. 2010. "Skilled-Unskilled Wage Gap in the Enlarged EU: Sectoral Analysis Based on the Experience of EU-15 Countries and Five New Member States.” 12th European Trade Study group conference, Lausanne, Switzerland.

Ronchi, Maddalena, and Filippo di Mauro. 2017. "Wage Bargaining Regimes and Firms' Adjustment to the Great Recession.” European Central Banking Working Paper 2015. European Central Bank, Frankfurt.

Rudebusch, Glenn, and John Williams. 2014. "A Wedge in the Dual Mandate: Monetary Policy and Long-Term Unemployment." Federal Reserve Bank of San Francisco Working Paper 2014-14.

Smith, Christopher L. 2014. "The Effect of Labor Slack on Wages: Evidence from StateLevel Relationships.” FEDS Notes, Federal Reserve Board, Washington, DC.

Stock, James H. 2011. "Discussion of Ball and Mazumder, 'Inflation Dynamics and the Great Recession.”’ Brookings Papers on Economic Activity 42 (1): 387-402.

Taylor, John. 2016. "The Staying Power of Staggered Wage and Price Setting Models in Macroeconomics.” NBER Working Paper 22356, National Bureau of Economic Research, Cambridge, MA. 
Trigari, Antonella. 2014. "Commentary: Long-Term Nonemployment and Job Displacement." Paper prepared for "Re-Evaluating Labor Market Dynamics," August 21-23, Jackson Hole, Wyoming.

Valletta, Robert G. 2016. "Recent Flattening in the Higher Education Wage Premium: Polarization, Skill Downgrading, or Both?” NBER Working Paper 22935, National Bureau of Economic Research, Cambridge, MA.

Watson, Mark W. 2014. "Inflation Persistence, the NAIRU, and the Great Recession," American Economic Review: Papers and Proceedings 104 (5): 31-36.

Wood, Adrian. 1991. "How Much Does Trade with the South Affect Workers in the North?" World Bank Research Observer 6: 19-36, Washington, DC.

-1994. North-South Trade, Employment and Inequality: Changing Fortunes in a Skill-Driven World. Oxford: Clarendon Press.

-1995. "How Trade Hurt Unskilled Workers.” Journal of Economic Perspectives 9 (3): 57-80.

Wooldridge, Jeffrey. 2009. “On Estimating Firm-Level Production Functions Using Proxy Variables to Control for Unobservables." Economic Letters 104 (3): 112-14.

Yellen, Janet L. 2005. Productivity and Inflation. Federal Reserve Bank of San Francisco Economic Letter.

—. 2014. "Labor Market Dynamics and Monetary Policy." Speech at Federal Reserve Bank of Kansas City Economic Symposium, Jackson Hole, Wyoming. https://www.federalreserve.gov/newsevents/speech/yellen20140822a.htm. 